Louisiana State University

LSU Digital Commons

1959

\title{
The Availability of Native and Radioactive Fertilizer Phosphorus to Oats on Lake Charles Clay.
}

Laron Eldon Golden

Louisiana State University and Agricultural \& Mechanical College

Follow this and additional works at: https://digitalcommons.Isu.edu/gradschool_disstheses

\section{Recommended Citation}

Golden, Laron Eldon, "The Availability of Native and Radioactive Fertilizer Phosphorus to Oats on Lake Charles Clay." (1959). LSU Historical Dissertations and Theses. 512.

https://digitalcommons.Isu.edu/gradschool_disstheses/512

This Dissertation is brought to you for free and open access by the Graduate School at LSU Digital Commons. It has been accepted for inclusion in LSU Historical Dissertations and Theses by an authorized administrator of LSU Digital Commons. For more information, please contact gradetd@lsu.edu. 
THE AVAILABILITY OF NATIVE

AND

RAIIOACT IVE, FERTILIZER PHOSPHORUS

TO OATS ON

LAKE CHARTES CLAY

\section{A Dissertation}

Submitted to the Graduate Faculty of the

Louisiana State University and Agricultural and Mechanical College

in partial fulfillment of the

requirements for the degree of

Doctor of Philosophy

in

The Department of Agronomy

Laron Ey ${ }^{c^{n}}$ Golden

B.S.A., University of Arkansas, 1949

M.S., Louisiana State University and

Agricultural and Mechanical College, 1951

January, 1959 


\section{ACKNOWI,IDGEMEHTS}

The writer wishes to express his sincere appreciation to Dr. M. B. Sturgis, Head of the Department of Agronomy, for his guidance in carrying out this study and in preparing the menuscript. The witer wishes also to thank Dr. M. T. Henderson, Professor of Agronom, for advice concerning analysis by statistical methods, Dr. William J. Upchurch, Associate Agronomist, for suggestions concerning chemical and radiological methods and Mr. C. B. Johnston, Professor of Chemistry, University of Houston, for making his laborgtories available to the

writer and for assisting in the procurenent and employment of $\mathrm{p}^{32}$. 
TABLE OT CONTEHTS

$\underline{\text { Page }}$

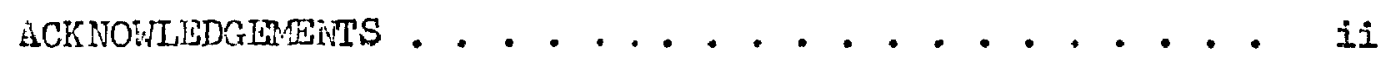
LIST OF TABLISS ............... . . iv LIST Di FIGURES. . . . . . . . . . . v v LIST OF PLATLS. . . . . . . . . . . vi

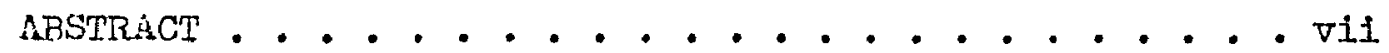

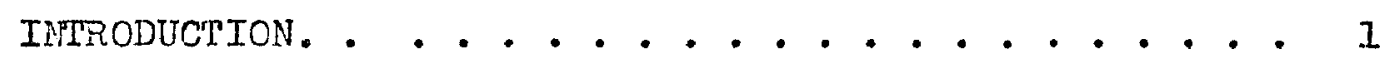
REVIELS OF LITERATURE. . . . . . . . . . . 3

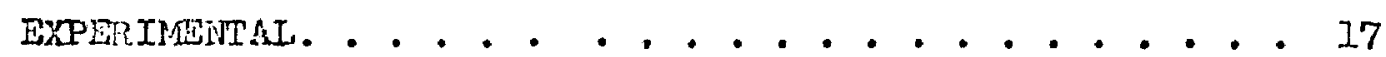
Materials and Methods. . . . . . . . . I7 Results and Discussion . . . . . . . . 34 SURARY AID CONCLUSIONS. . . . ........ 66 IITERATURE CITED. . . . . . . . . . . . 69 AUTOBIOGRAPHY. . . . . . . . . . . . 77 
1. Effects of soil phosphorus, fertilizer phosphorus and placement on the yield of oats and the soil phosphorus and fertilizer phosphorus in the oet plants harvested 4 weeks after date of planting.

2. Tffects of soil phosphorus, fertilizer phosphorus and placement on the yield of oats and the soil phosphorus and fertilizer phosphorus in the oat plants harvestied 8 weeks arter date of planting.

3. Erfects of soil phosphorus, fertilizer phosphorus and placement on the yield of oots and the soil phosphorus and fertilizer phosphorus in the oat plants harvested 12 weeks sfter date of planting.

4. Effects of soil phosphorus, fertilizer phosphorus and placement on the yield of oats and the phosphorus content of oet plants harvested at maturity.

5. Relationships of soil phosphorus, fertilizer phosphorus, placement and period of growth of oats to the amounts of phosphorus extrected from Lake Charles clay at different sampling periods by three extractants.

6. Lffects of fertilizer mixed well with Lake Charles cley on the amounts of phosphorus soluble in three extractants at ijfferent samoling periods after epplication of fertilizer to soil which remained unaropoed.

7. Fried and Dean A-values and soil phosphorus actually absorbed without phosphorus being added.

8. Movement of phosphorus fiom bended 12-12-12 fertilizer in Lake Charles clay as indicated by radioactivity of soil samples. 
IIST OT PIGURES

Number

Page

1. Example of calibration curve for determining amounts 28 of radioactive phosphorus in samples.

2. Efrects of soil phosphorus, fertilizer phosphorus 36 and placement on yield of oats.

3. Effects of soil phosphorus, fertilizer phosphorus and placement on phosphorus content of oats.

4. Effects of banding and of mixing 1.2-12-12 fertilizer on the uptake of soil and fertilizer phosphorus by oats.

5. Effects of extractents and soil to extractant ratios 56 on the phosphorus dissolved from Lake Chrles cley in which 12-12-12 and 12-0-12 hed been mixed 4 weeks previously. 


\section{IIST OF PLATES}

Number

Page

1. Photograph of the cold frame used to house the

22 oats and soil in the various treatments.

2. Photograph of the cold frame with the elevator platform in its top-most position.

3. Photograph of a tub used to wash the soil free from the roots at each harvest period.

4. Photograph of the oat plants harvested at the 4-week harvest period.

5. Fhotograph of the oat plants hervested at the 8 -week harvest period.

6. Photograph of the oat plants harvested at the 12-week harvest period.

7. Fhotograph of the oat plants harvested at maturity. 
ABSTRACT

A study of the availability of native and radioactive fertilizer phosphorus was conducted in 1956 and 1957 at the University of Houston using Iake Charles clay in pots planted to oats. The yields at 4 harvest periods from replicated pots, treated with 12-12-12 and 12-0-12 fertilizers, each banded and each mixed with the soil, were studied in relation to absorption of phosphorus. Phosphorus fixation, as related to time of fertilizer contact with the soil, was determined. The relationships of phosphorus obtained from the soil by different extractants to phosphorus absorbed by plants and to Fried and Dean A-values were observed.

The greater yield of oats at all harvests from each $12-12-12$ treatment, as compared to the yield from the respective 12-0-12 treatment, was highly significant. Yield of oats from the 12-12-12-banded treatment at each of the forage harvests was significantly higher than that from the 12-12-12-mixad treatment. No significant difference occurred between grain yields from the 12-12-12-banded and the 12-12-12mixed treatments. Neither forage or grain yields from the 12-0-12-banded and the 12-0-12-mixed treatments were significantly different at any harvest.

The phosphorus content of plants treated with phosphorus was higher throughout the experiment than the phosphorus content of plants not treated with phosphorus. Until the 8-week harvest, the phosphorus convil 
tent of plants receiving the 12-12-12-bended treatment was higher than that of plants receiving the 12-12-12-mixed treatment. Following this period, no appreciable differences occurred in phosphorus content of plants from the two treatments.

During the period of observation, more fertilizer phosphorus was absorbed by plants in the 12-12-12-banded treatment than was absorbed by plants in the 12-12-12-mixed treatment. More soil phosphorus, however was absorbed by oats in the 12-12-12-mixed treatment. Fried and Dean A-values from the 12-12-12 treatments were higher than the actual amounts of phosphorus absorbed by plants from the 12-0-12 treatments. Only a slight tendency toward additional phosphorus fixation occurred after 4 weeks follcwing mixing fertilizer with the soil.

Phosphorus extracted from the soil by use of the $0.1 \mathrm{~N} \mathrm{HCI}+0.03$ $\mathrm{N} \mathrm{NH} 4_{4} \mathrm{~F}$ solution mors nearly characterized the phosphorus avallable to plants than that extracted by either of the other extractants. Phosphorus values obtained by using the $0.1 \mathrm{~N} \mathrm{HCl}+0.03 \mathrm{~N} \mathrm{NH}_{4}{ }^{\mathrm{F}}$ solution compared favorably with Fried and Dean A-values.

Phosphorus movement from the fertilizer band during the period of observation was negligible. 


\section{INTRODUCTICN}

Hith the population of the United States increasing at a rate in excess of two and onemalf millions of people per year and with the normal Ilfe expectancy of man rising, demand for farm products will continue at a high level for many decades. Erenthough production may oecesionally exceed demand, higher and higher yields of crops must be sought to provide food and clothing for a rapidiy increasing population which has relatively ifttle additional acreage from which to obtain more of the necessities of life. The perennial cost-price squeeze on the farmer 1 s demanding that he learn as moh as he can about kinds and am mounts of fertilizers to use as well as about methods for application of fertilizers for the production of maximm ylelds.

The responsibility for provlding accurate information conoerning kinds, amounts and methods of placement of fertilizers rests upon the soll sclentists who mat continue to search for better chemicals, machines and methods for fertilizer application. Better methods for making soil tests which will glve more definite deta as bases for fertilizer recomendations are needed.

of the three major essential plant nutrient elements, nitrogen phosphorus and potassium, phosphorus may be considered to be the most critical because of the relatively low amount of it in average solis and because of the relatively low solublilty of it.

Many cultivated so11s in the southern part of the United States hare 
received five to six times the amount of phosphorus in fertilizers as has been removed by crops. An accumulation of phosphorus has therefore occurred in many of these older cultivated solls. This accumalated phosphorus apparently becomes slowly available to subsequent crops but the avallability is of a vory low degree.

Rarely over thirty per cent of applied phosphorus finds its way Into the crop during the season of its application and relatively less of the residual phosphorus is available to later crops. In some soils, particularly in those having a high phosphate fixing capacity, new materials and better methods for their application are neoded to inorease the efficlency of the use of phosphorus by the crops. Chemioal agents which will extract phosphorus in amounts that can be correlated with the amounts removed by crops are also of major importance.

The purposes of this experiment have been to study the effects of fertilizer placements on phosphorus content and yield of oats grown in Lake Charles olay, to determine the relationships between soluble phosphorus obtained with three different extracting agente, the fertiIlzer and soll phosphorus absorbed by the oats and their relationships to crop yield and to ascertain the degree to which applied phosphorus is fIxed with respect to time. 


\section{REVIEW OF IITERATURE}

Lake Charles clay soll occuples an important agricultural position among the Coastal Prairie soils of Ioulsiane and Texas (11, 34, 81). Carter (11) states that the soils of the Coastal Prairie of Texas have been developed largely from marl under a heavy grass cover. He states that most of the dark-colored Coastal Prairle solls are of the Iake Charles serles. He reports the Lake Charles solls to be black to darkgray in color, with dark-gray heavy clay subsolls in many places resting on marl or slightly calcareous clay at a depth of several feet. He found the soils to be deep and in most places slightly acid in reaction. These solls occupy large smooth nearly flat areas of great uniformity in surface relief and soil character. He says that the principal soil is the clay. Fraps (34) reports the following concerning Lake Charles clay soil samples taken in the Coastal Prairie Region in Jefferson County, Texas:

\begin{tabular}{|c|c|c|c|c|c|c|}
\hline \multirow{2}{*}{\multicolumn{2}{|c|}{$\frac{\text { Phosphorie Acid }}{\text { Total Active }}$}} & \multicolumn{3}{|c|}{ Potash ${ }^{*}$} & \multirow[b]{2}{*}{ Nitrogen ${ }^{*}$} & \multirow{2}{*}{$\begin{array}{l}\text { Acid-soluble } \\
\text { Ilme }\end{array}$} \\
\hline & & Total & Acid-solublo & Active & & \\
\hline $\begin{array}{l}\text { Surface } 800 \\
\text { soil }\end{array}$ & 73 & 11000 & 7400 & 239 & 2680 & 11200 \\
\hline Subso11 1140 & 19 & 12200 & 6800 & 223 & 1600 & 10000 \\
\hline
\end{tabular}

The availability of soil and of fertilizer phosphorus to plants is of graat Importance. An excellent review of Ilterature on this subject has been presented by Pierre and others (74). Total phosphorus in agricultural soils normeliy varies from 400 parts per milition to 1000 
parts per million. Phosphorus normally considered to be available to to plants may vary from a few parts per million to 300 parts per million depending on the soll and the method used for the determination of "available" phosphorus (10, 21, 31, 90, 99). Parker (69) found corn plants to grow normally in culture solutions containing 0.25 p.p.m. $\mathrm{PO}_{4}$ provided this concentration was constantly maintained. Growth was restrioted at 0.1 p.p.m. $\mathrm{PO}_{4^{*}}$ Fried, Hagen, Salz zol Rio and Loggett (38) found phosphorus absorption rate by an acre of plants to be less than soll solution phosphorus formation rate by a factor of at least 250 . Dean and Rubins (23), in studies concerning absorption of phosphorus by plants from a clay-water system, found no evidence of a contact exchange or other contact effect between plant roots and clay particles which affected the rate of absorption of phosphorus from clay-water systems. It appeared to them that under certain conditions roots of plants lose phosphorus to a surrounding clay-water system. Dean and Gledhill (21) believe that a reduced phosphate absorption by roots in contact with dry soil may occur as a result of alterations in the physiology of roots. Kittrick and Jackson (53) suggest that the increase in solI phosphate surface area accounts for the beneficial effects of phosphate fertillzation once the fertilizer has reacted with the soll. Islam (49) belleves that the abeorption of adsorbed phosphorus by plants is increased by increasing the degree of saturation of the colloid with respect to phosphorus. Lewis, Jordan and Juve (55) found phosphate fertilization to increase the availability of soll phosphorus. Many theories concerning the forms of phosphorus in soils and the mechanisms of retention and release of phosphorus by soils have been 
published in recent years $(4,16,18,19,20,25,35,46,72,76,79$, $80,95,102,104)$. The recovery of fertilizer phosphorus by the crop that is planted immediately after the fertilizer application amounts to only 10 to 30 per cent of the quantity added to the soll, according to Hemwall (43), and the remaining 70 to 90 per cent has been assumed to be consumed by microorganisms, precipitated by soluble cations in the soil solution, or sorbed by the soil complex. Hemwall further states that it is now generally accepted that the part played by soll mieroorganisms is relatively minor and that chemical precipitation and physicochemical sorption play the major roles. Jackson (50), however, reports average conversions of applied phosphate into organic form to be as high as 20 to 30 per cent in the top inch of soil. In recently formed alluvium he found only negltgible conversion to organic form. Ravikovitch (78), in a study of the influence of exchangeable cations on the availability of phosphate in so1ls, arranged cations in the following order according to their effectiveness in $\mathrm{PO}_{4}$ adsorption: $\mathrm{Ca}>\mathrm{Mg}>\mathrm{H}>\mathrm{MH}_{4}>\mathrm{Na}$. He found the combination of the soll complex with the $\mathrm{PO}_{4}$ ion and exchangeable calcium to be very unstable under the action of very weak acids. He found the availability of the $\mathrm{PO}_{4}$ fon adsorbed by the H-complex to be low. Scarseth (87), in a study with natural alumino-rilicate collolds, found the phosphate lons to be replaced by OH and $\mathrm{SiO}_{4}$ anions. He believed that phosphates retained at the pH values $5.5-6.1$ were sorbed on the colloldal surfaces of the alumino-silicate by the aluminum valence. Stout (93), from an Xray analysis of altarations in the crystal structure of clay minerals, 
concluded that measurements of the loss of water from the system of kaolinite and from the system of kaolinite plus potessium acld phosphate accounted for the exchange of phosphate ions for hydroxyl ions of the crystal lattice of kaolinite. He states that kaolinite has a sheot of hydroxyl ions at one side of the basal cleavage plane and a sheet of oxygen Ions on the other and that bentonfite is cumpoed of mica or pyrophyllite-like layers and has a sheet of oxygen ions on both sides of the basal cleavage plane. He suggests that the relative abilities of kaolinite and bentonite to fix phosphate are related to the hydroxyl Ions available for exchange with phosphate lons. Russell and Low (85), In an experiment concerned with reactions of phosphate with kaolinite, concluded that aluminum adsorbed on the colloidal surface precipitates added phosphate as an aluminum phosphate on the kaolinite surface. EIIIs and Truog (29) present evidence which indicates that phosphorus fixed by calcium-saturated montmorillonite is fixed as celcium phosphate complexes and not by a $\mathrm{H}_{2} \mathrm{PO}_{4}-\mathrm{Ca}-\mathrm{clay}$ bonding as has bean proposed. Ford (32) found phosphorus fixed by soils as calcium and magnesium phosphates to be readily soluble in weak solvents and, therefore, readily available to plants. He found the phosphorus fixed as ferric and aluminum phosphates by ferric and aluminum hydroxides, chlorides or sulfates to be at least in part easily hydrolizable and available to plants while that fixed by limonite was very insoluble and only slowly avallable to plants. Scarseth and Tidmore (88) found the amount of available phosphete in soll collolds to vary directly with the silicamsesquioxide ratio of the colloids. Hemwall (44) obtained results which indicated 
that phosphorus is fixed in soils as $\mathrm{AlPO}_{4} \cdot 2 \mathrm{H}_{2} \mathrm{O}$ by reacting with soluble aluminum which originates from exchange sites or from lattice dissociation of clay minerals.

The effects of such factors as time, temperature, Iime content and weathering of solls on the degree and kind of phosphorus fixation and of phosphorus avallability to plants has drawn considerable artention among soil scientists. Kurtz, DeTurk and Bray (54) showed that with additional time following phosphate application there was not only a gradual increase in the amount of phosphate adsorbed but also a gradual change in the status of the adsorbed phosphate. This was shown by decreases in the amounts of phosphate which could be removed by water and by an increase in the easily acid-soluble fraction. The bulk of the added phosphate, however, was retained in the adsorbed form from which it was displaced by the fluoride ion in a neutral solution. Fll, Black and Kempthorne (28), in studying the importance of soil organic and Inorganic phosphorus to plant growth at low and at high temperatures, found that at a soil temperature of $20^{\circ} \mathrm{C}$ the avallability of soil phosphorus to plants was limited almost entirely by the inorganic fraction. They found that at a soil temperature of $35^{\circ} \mathrm{C}$ both inorganic and organic fractions were significantly related to the amount of plantavallable phosphorus. Davis (17), who studied the sorption of phosphates by nonmcalcareous Hawaitan soils, found fixation to be reversed very slowly. He considered this to be evidence that the phenomenon of $f(x-$ ation of phosphates cannot be ascribed to adsorption. He found cations to be adsorbed along with the phosphate applied and that the degree of 
fixation was a function of the hydrogen-ion concentration of the solution. Fraps (35), in a comparison of fixation of phosphorus at different temperatures, showed that with some soils, considerable increases in phosphorus-eixation occurred when the temperature increased. In an examination of 761 surface soils and 651 subsolls, he found the percentages of phosphoric acid fixed increased. Cook (14) found that increasing the base saturation of solls by liming caused an increase In the amount of readily avallable soll phosphorus. He also found that additions of lime to acid solls lowered the power of those soils to fix added phosphorus. Perkins, Draggdorf, Lippincott, Selby and Fateloy (72) found indications that decomposition of the soll clay minerals may be responsible for a major part of the phosphate fixation in soils. Mang chemical methods have been used for the determination of forms and amounts of phosphorus in soils and in plant tissue $(8,26,30$, $36,39,42,52,64,65,71,89,96,97,105)$. MAller and Axloy $(64)$ state that chemical methods for determining available phosphorus in soils were first studied about a century ago. Baver and Brunner (3), In using an ammonium molybdate solution and stannous oxalate for the determination of readily soluble phosphorus in Missouri solls, found It necessary to filter soil extracts to remove organic matter. They found organic matter to hinder color development and iron-manganese concrations to intensify color development when the ammonium molybdate was placed in the extracting solution. In this work they concluded that no rapid soil test is universally applicable to all soils or soil conditions and that the tendancy towards the use of a universa. 
extractant for all nutrients is resulting in less reliable data than when a specific extractant for each nutrient is used. Dickman and Bray (27) report that complete recovery of phosphate added to kaolinite was obtained by shaking 1 gram of kaolinite with 50 milliliters of a $0.1 \mathrm{~N}$ neutral $\mathrm{NH}_{4} \mathrm{~F}$ solution for 1 minute. They state that some of the Inorganic forms of phosphates in soils include water-soluble phosphates, calclum phosphates of varying solubilities, iron and aluminum phosphates and adsorbed or replaceable phosphates. Weeks and Karraker (10I), In a comparison of various extracting solutions for measuring the availability of phosphorus in so1ls, found that the conditions under which the extraction procedure was carried out affected the results to a certain extent but generally not enough to change the relation of one extractant to the others. Islam (48), In a study of the role of the solid phase of phosphorus in the nutrition of plants, found low amounts of soluble phosphorus in Aikan clay loam, and by comparing the good growth from this soll and other soils having relatively high amounts of soluble phosphorus; he concluded that solubility is not the only criterion of phosphorus availability and that plants possibly utilize fixed phosphorus from the solid phase. Bray and Kurtz (9) state that most of the methods omploying acids or acids buffered to definite pH values have been extracting easily acid-soluble forms more or less offectively but have been relatively less effective in extracting the adsorbed forms except where these were present in large amounts. Furthermore, they state, it has been shown that as these latter forms increase in amount their solubility in water increases rapidly which 
explains why the acid reagents remove relatively more of them when they are present in high amounts. This also expleins why the adsorbed forms are the most effective forms of phosphorus in the soil for plants, once adequate amounts have been built up, but when they are present in very small amounts their solubility is very low and they then appear to be relatively Ineffective. Bray and Kurtz balieve that the only important difference between methods of determinetion of phosphorus in solls Iies In the extracting solution used. They further state that there is little to be gained by applying quantitative methods for phosphorus or ang other nutrient to a soll extzact when the extracting solution has not removed the correct forms of the nutrient quantitatively or at least in amount proportional to the total present. They used a solution of $0.025 \mathrm{~N} \mathrm{HCl}+0.03 \mathrm{~N} \mathrm{NH}_{4} \mathrm{~F}$ as an extractant for the removal of "adsorbed" phosphorus, a solution of $0.1 \mathrm{~N} \mathrm{HCI}+0.03 \mathrm{~N} \mathrm{NH} 4 \mathrm{~F}$ as an extractant for the removel of "adsorbed" and acid-soluble phosphorus and a solution of $0.1 \mathrm{~N} \mathrm{HCl}+0.5 \mathrm{~N} \mathrm{NH}_{4} \mathrm{~F}^{\prime}$ as an extractant for total acid-soluble and adsorbed phosphorus. They found that use of a solution of $0.1 \mathrm{NHCl}+0.03 \mathrm{~N} \mathrm{NH}_{4} \mathrm{~F}$ gave the best correlation between the values obtained and crop responses to added phosphates for the usuel corn belt crops. Kurtz, DeTurk and Bray (54), studyling phosphate adsorption of Illinols solls, found the phosphate-replacing ability of different anions to be in the followlng order: fluoride>oxalate>citrate>bicarbonate $>$ borete $>$ acetate $>$ thiocyanate $>$ sulfate $>$ chloride. Byside and Sturgis (10) proposed \& modification of Bray's method for the removal of "adsorbed" and acid-soluble phosphorus and found the proposed 
method to yleld results which were more highly correlated with fosponse of sugar cane to fertilizer phosphorus than the methodis of Bray, of Truog and of methods involving extracting by use of $0.1 \mathrm{~N} \mathrm{H}_{2} \mathrm{SO}_{4}$ or 0.1 . N HCl. Reed and Sturgis (82), following work concerned with chemical methods for the dotermination of available nutrients in Iouisiana soils, roport that fairly good agrements with field results were obteined from the use of La Motte kits and by means of the laboratory method involving extraction with $0.05 \mathrm{NHCl}$. They did not find that routine sampling, testing and interpretation can be made by persons unfamiliar with the techniques of the methods and the nature of the solls and crops. Cotton (15) states that quantitative colorimetric estimation of phosphorus prosent in microquantities is carried out almost univeraally by the molybdenum blue reaction and that the reaction is sensitive to very small amounts of phosphorus. He postulates the reaction to be as follows: Orthophosphate Ions cetalyze the reduction of soluble molybdates by stannous chloride or other reducing agent to a blue complex having molybdenum present in 5 and 6-valent forms. Rost and Pinckney (84), from a study of colorimetric methods for the determination of readily available phosphorus in soils, found that using results of tests of surface samples only was about as reliable as uging results of tests obtained from samples of mixed surface soll and subsoll.

Fried and Dean (37) have proposed a method whereby the avallability of native soil phosphorus may be approximated by the employment of a standard containing phosphorus. They summarized this work by stating: "The concept that a plant having two sources of a nutrient will absorb 
Its nutrients from each of these sources in direct proportion to the amounts arallable has the following loglcal sequence: The quantity of available nutrient in the soil can be determined in terms of a standard, provided the proportion of the nutrient in the plant derived from the stendard is determined. The mathematical expression of this relationship is

$$
A=\frac{B(1-y)}{y}
$$

where A = emount of nutrient avajlable in the so1I; B = amount of nutrient in the standard; $y=$ proportion of the nutrient in the plant derived from the standara." The amount of the nutrient in the plant derived from the standard may be determinod by radioisotopo techniques (12). This amount may then be divided by the total amount of the nutrient in the plant to obtain the proportion of the nutrient in the plant derived from the standerd.

The use of radioisotopes in soil fertility and plant nutrition studies has increased many fold in the past two decades $(2,7,12,13$, $41,63,68,75,92,103)$. Basic concepts and techniques for agricultural use of radiolsotopes are presented by Hendricks and others $(22,45,57,61,67,94,98)$. According to Rabideau (77), radioactive isotopes were first used in the study of the absorption and distribution of mineral elements by plants in 1923. The isotope, $\mathrm{p}^{32}$, a high energy beta emftter, lends 1tself most admirably to a study of chemical and blological systems (12). Comar (12) and McAuliffe (59) have found it satisfactory from the standpoint of sensitivity and reproducibility to make all assays of the high energy emitters in solution. They note 
that one disadvantage of using a dipping-type tube, as compared to the thin-mice-window tube used for assay of dry samples, is that the dipping-type tube mast be brought back to background count following exch measurement of radioactivity. Howarth (47), in making solution counts, found it desirable that the fluid medium be either a solution of the substance or a fine, stable, homogeneous suspension which permits dilution and the removal of representative samples. He found coarse suspensions to give erratic counting rates, due, in part, to drifting of suspended material. Mackenzie and Dean (56) found the use of briquets to be satisfactory for the assay of $\mathrm{P}^{32}$ in plant material. Briquets were made by pressing approximately 5-gram samples in cylinders for 3 minutes at 12,000 pounds per square inch pressure. The resulting samples were $11 / 8$ inch in diameter and approximately $1 / 4$ Inch thick. In a study of radioactivity of briquets prepared identically with weight of sample as a variable, Mackengie and Dean found that infinite thickness of sample was reached at approximately 3 grams of sample. Rabideau, Whaley and Heimsch (77), in making radioactivity assays of corn plants, used circular or rectangular pleces of leaf or internode samples. The samples to be compared were taken from simflax locations on different plants. The leaf and internode samples were glued to microscope slides to prevent curling. They found that they were able to obtain results from a large number of samples in a relatively short period of time and that this method has merit notwithstanding the fact that measurenents on a comparable woight basis are desirable.

The use of radioisotopes in plant nutrition experiments is justifable 
only when it can be shom that the radiation to which the plant is exposed has no appreciable effect upon the growth and ion intake of the plant (5). Tolbert and Pearson (98) state that, in general, it takes several thousand roentgens of external radiation to cause visible plant damage but only several hundred roentgens to injure animals. Thery add, however, thet plants are affected by low levels of radiation such as that from $\mathrm{P} 32$ because of the facts that $\mathrm{P}^{32}$ accumulates in the growing tips and that the dividing cells there are most sensitive to radiation. Blume (5), In a study of the radiation effects on plants grow in soil treated with fertilizer containing $\mathrm{P}^{32}$ in amounts from 0 to 12,500 microcuries per gram of $\mathrm{P}^{31}$, found that, eventhough differm ences in dry weights of tops, phosphorus content of tops and the percentage of phosphorus in tops derived from the fertilizer were sometimes significant, the differences were too small to appreciably affect the data geined by the use of the 1sotope. From a study concerned with radiation injury to plants grow in nutrient solutions containing $\mathrm{P}^{32}$, Blume, Hagen and Mackie (6) found that the lowest level at which damage was produced corresponded to 5.6 millicurles of $\mathrm{P}^{32}$ per gram of $\mathrm{P}_{2} \mathrm{O}_{5}$. Other investigators $(58,70,86)$ have found varying degrees of plant injury during plant mutrition studies involving the use of $\mathrm{p} 32$.

The effect of placoment of phosphorus on the phosphorus availability and utilization by plants has been studied congiderably during recent years. Pesels (73), In a study of the effect of source and placement of phosphorus, reports that either broadcasting or drilling superphosphate and calcium metaphosphate was an effective means of 
supplying additional phosphorus to established meadows. Riewe and Smith (83) found phosphate broadcast on Lake Charles clay soll to be utilized more efficiently by Dallis grass and white clover than phosphate placed In subsurface bands 7 inches apart and 2 inches deep. McAuliffe and Bradfield (60) found at the end of the first cutting of Sudan grass that plant absorption of phosphorus from superphosphate applied in the 8-10 inch layer of soil was 45 to 78 per cent as great as that from the 1-3 inch layer. They reported that phosphorus absorbed from the 1/4-16 inch layer was 10 to 17 per cent as much as that from the surface layer. By the third cutting, these absorption percentages had increased to 77-80 and 38-75 respectively. They sampled the soll proflile at half-inch intervals and found only slight vertical movement of phosphorus in the soil at the end of 3 months. Allen, Speer, and Maloney (I), in a phosphate placement study with vetch and wheat, found surface application to be unsatisfactory. They found banded phosphate to be most efficiently used by wheat when placed at a depth of 8 inches while phosphate placed at depths of 2 to 4 inches gave the best results with vetch. In the uncropped soil, the availability of phosphate decreased approximately 70 per cent in 7 months. Jordan, Simkins, Corey, Knight and Baker (5I), in an experiment concerned with the effect of placement of fertilizer phosphorus on the growth of potatoes, reported that band application provided more fertilizer phosphorus for plant use in earliest stages of growth than did broadcast application. When plants were 6 to 12 inches high, however, the broadcast treatment was supplying more fertilizer phosphorus then the band treatment. 
Phosphorus applied to soils presumably deficient in phosphorus may or may not cause an increase to occur in the phosphorus content of plants growing on those soils. MoLean (62) found that phosphate fertiIization of oats on Newtonia loam caused an Increase in the phosphorus content of the oats. Fraps (33) found no relation between the addition and the per cent phosphoric acid in corn, millet, mustard or kaffir. others $(40,51,68,75)$ have found widely varying relationships between applied phosphorus and phosphorus content of plants expressed as per cent. 


\section{EXPERIMENTAL}

Materials and Methods

A composite of approximately 800 pounds of Lake Charles clay soil was taken from a 5-acre native pasture on the University of Houston Demonstration Farm in Pasadena, Texas. Soll type and Its location was identified in Harris County Soll Survey of 1922. A sample from this batch of soil was analyzed by the soil testing laboratory at Louisiana State University. Results of this soil analysis are show below:

\begin{tabular}{lcl}
\hline \hline & Chemical values & $\begin{array}{c}\text { Classification } \\
\text { of results }\end{array}$ \\
\hline Reaction - pH & 6.1 & Medium \\
Organic matter, $\%$ & 3.7 & High \\
Total nitrogen, $\%$ & High \\
Total phosphorus, p.p.m. & 0.15 & Low \\
Available phosphorus, p.p.m. & 187 & Very Iow \\
Available potassium, p.p.m. & 6 & Medium \\
Available calcium, p.p.m. & 182 & Medium \\
Available magnesium, p.p.m. & 3024 & High \\
\hline
\end{tabular}

Results of a particle size analysis of a separate sample of this soll are as follows: 9 per cent sand, 35 per cent silt and 56 per cent clay. After the soll material collected had been air-drfed and thoroughly mixed, approximately 400 pounds were ground with a hand mill and sieved 
to pass a 6-mesh screen. The sieved soil was mixed thoroughly again. Samples of this soll. were sieved to determine aggregate size distribution. The distribution of different aggregate sizes was as follows:

Aggregate size analysis of Lake Charles clay using United States Standard Sieves.

\begin{tabular}{ccc}
\hline Sieve number & Tyler equivalent & $\begin{array}{c}\text { Per cent of } \\
\text { sample retained }\end{array}$ \\
18 & 16 & 49.0 \\
40 & 35 & 24.3 \\
60 & 60 & 9.0 \\
140 & 150 & 11.2 \\
140 or finer & 150 or finer & 6.5 \\
\hline
\end{tabular}

Thoroughly sieved and mixed soil in the amount of 6.8 pounds was weighed for each of 54 containers or pots required for the experiment. The containers were tinned cans coated on the inside with clear varnish. The pots were 6 inches in diameter and 6.8 inches in helght.

There were 4 different fertilizer treatments applied to the soil which was then planted to oats:

1. The soil in 12 pots was treated with 1.855 grams per pot or 1200 pounds per acre of pulverulent 12-0-12 obtained from the United States Department of Agriculture Plant Industry Station, Beltaville, Maryland. The fertilizer was placed in a horizontal band 0.5 inch wide and 1.5 inches deep. Then on the same day, October 15, 1956, 0.37 gram of oata or approximately 14 seed of the Alamo variety were planted in a single row in each pot 0.5 inch deep and directly over the band of 
fertilizer. On an acre basis the amount of oats planted amounted to 6.5 bushels per acre. The pots were moistened and arranged as described later in a cold frame. There were 3 pots or replicates of the treatment and these were harvested and soil samples were taken at 4 different tines, 4,8 and 12 weeks after planting and at maturity. Detailed methods of harvesting and of sampling soll are described later. 2. In 12 pots, the soil was treated with 1.855 grams per pot or 1200 pounds per acre of pulverulent 12-0-12 which was thoroughly mixed with the soil. Oat seed in the same amount as described above were planted 0.5 inch deep on October 15, 1956, in a single row in each pot. Procurement of fertilizer, molstening and harvesting were accomplished in the same manner as in Treatment 1. The methods of sampling the soil are described later.

3. The so1I in 12 pots was treated with 1.855 grams per pot or 1200 pounds per acre of pulverulent 12-12-12. This fertilizer was also procured from the United States Department of Agriculture Plant Industry Station, Beltsville, Maryland. It analyzed 12.4 per cent $\mathrm{P}_{2} \mathrm{O}_{5}$ or, in effect, $230.0 \mathrm{mg}$. of $\mathrm{P}_{2} \mathrm{O}_{5}$ or $100.3 \mathrm{mg}$. of $\mathrm{P}$, or $32.5 \mathrm{p} . \mathrm{p} . \mathrm{m}$. of $\mathrm{P}$ were applied to each pot. Specific activity of this fertilizer upon removal from the atomic pile on September 26, 1956, was 0.15 millicuries per gram of $\mathrm{P}_{2} \mathrm{O}_{5}$. Placement of fertilizer, planting, moistening and harvesting were done in the same manner as in Treatment 1. The method of sampling the soil is described later.

4. Each of 12 pots of the soil was treated with 1.855 grams per pot or 1200 pounds per acre of pulverulent 12-12-12 which was mixed 
with the soll. This fertilizer was also obtained from Beltsville and had the same activity as that used in Treatment 3. The planting, molstening, sampling of soll and harvesting of the series of pots under this fertilizer treatment wore identical to those given pots in Treatment 2 .

There were 2 different fertilizer treatments applied to the soll which was not planted to oats:

5. The soll in 3 pots was treated with 1.855 grams per pot or 1200 pounds per acre of pulverulent 12-0-12 which was thoroughly mixed with the soil. The pots were then moistened and arranged in the cold frame as described later and soil samples were taken at 4 different times, 4, 8, 12 and 22 weeks after application of fertilizer. The method of sampling the soil is described later.

6. The soll in 3 pots was treated with 1.855 grams per pot or 1200 pounds per acre of pulverulent 12-12-12 which was thoroughly mixed with the soil. This fertilizer was obtained in the same manner and contained the same amount of $\mathrm{P}_{2} \mathrm{O}_{5}$ and radioactivity as that used in Treatment 3. Molstening and sampling were done in the same manner as for Treatment 5.

Al1 54 pots were molstened by placing them in Size 2 tubs to which distilled water was added to a depth of 4 inches and maintained at that level until water had completely moistened the surface of each soil by movement through perforations in the bottoms of the pots. Each pot was then raised above the water and permitted to drain until dripping stopped. The radioactivity of the water drained from the pots treated with fertilizer containing $\mathrm{p} 32$ was found to be negligible. This water 
was drained into a sump in an isolated area on the University of Houston Demonstration Farm and covered with soil to a depth of 3 feet. All treatments were kept under semi-greenhouse conditions in a cold frame constructed for the purpose of housing the plants and soil used in this study. A photograph of the cold frame appears as Plate 1. The cold frame was 6 feet wide and 8 feet long. It was 5 feet high on the rear or north side and 4.5 feet high on the front or south side. The rear wall was of solid board construction. The front and side walls were partially made of transparent plastic covered screen of approximately 3 mesh tacked to a wooden frame. A cover made also of the plastic covered screen was firmly attached to the top of the rear of the cold frame and rolled over the top of the cold frame when deemed necessary. An elevator platform on which containers were placed was raised to its top-most position each morning as shown in Plate 2. The platform was lowered each night and during periods of inclement weather. The pots which were not planted to oats were placed at the west end of the platform. All other pots were arranged on the platform at random and were relocated at random once each week. The soll in all pots was kept near the moisture equivalent by watering as needed with distilled water. No rain was permitted to fall on the pots.

The oat plants were harvested at each harvest period by cutting the tops of the plants from the roots at the soll level. The roots were harvested from the pots at each harvest period by washing the soil free from the roots in Size 2 tubs. A tub containing soil that was sampled and roots that were harvested at the 8-week harvest appears as Plate 3. The root harvesting was done by agitating the soil and root mass by 


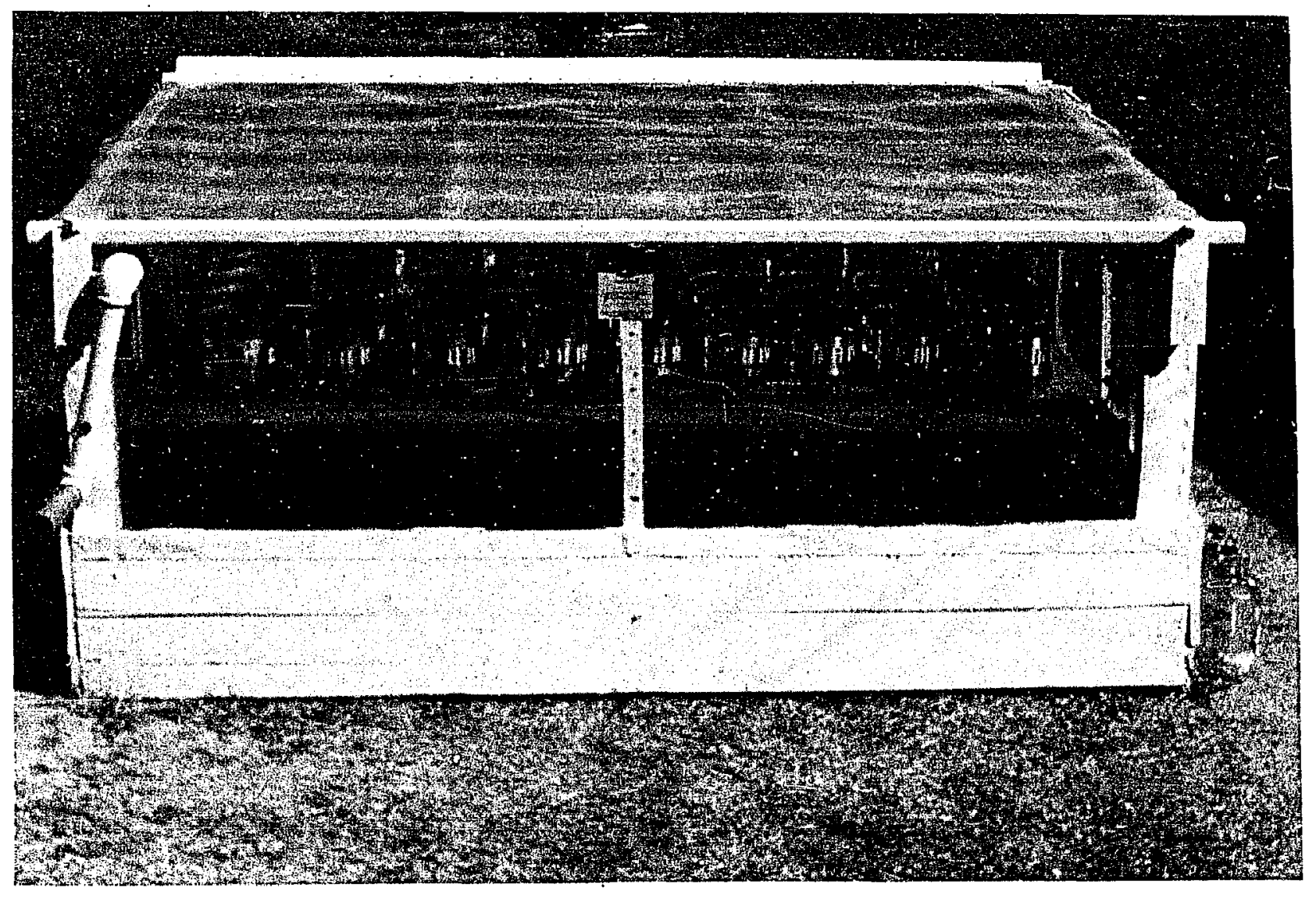

Plate 1. Photograph of the cold frame used to house the oats and soll in the various treatments. 


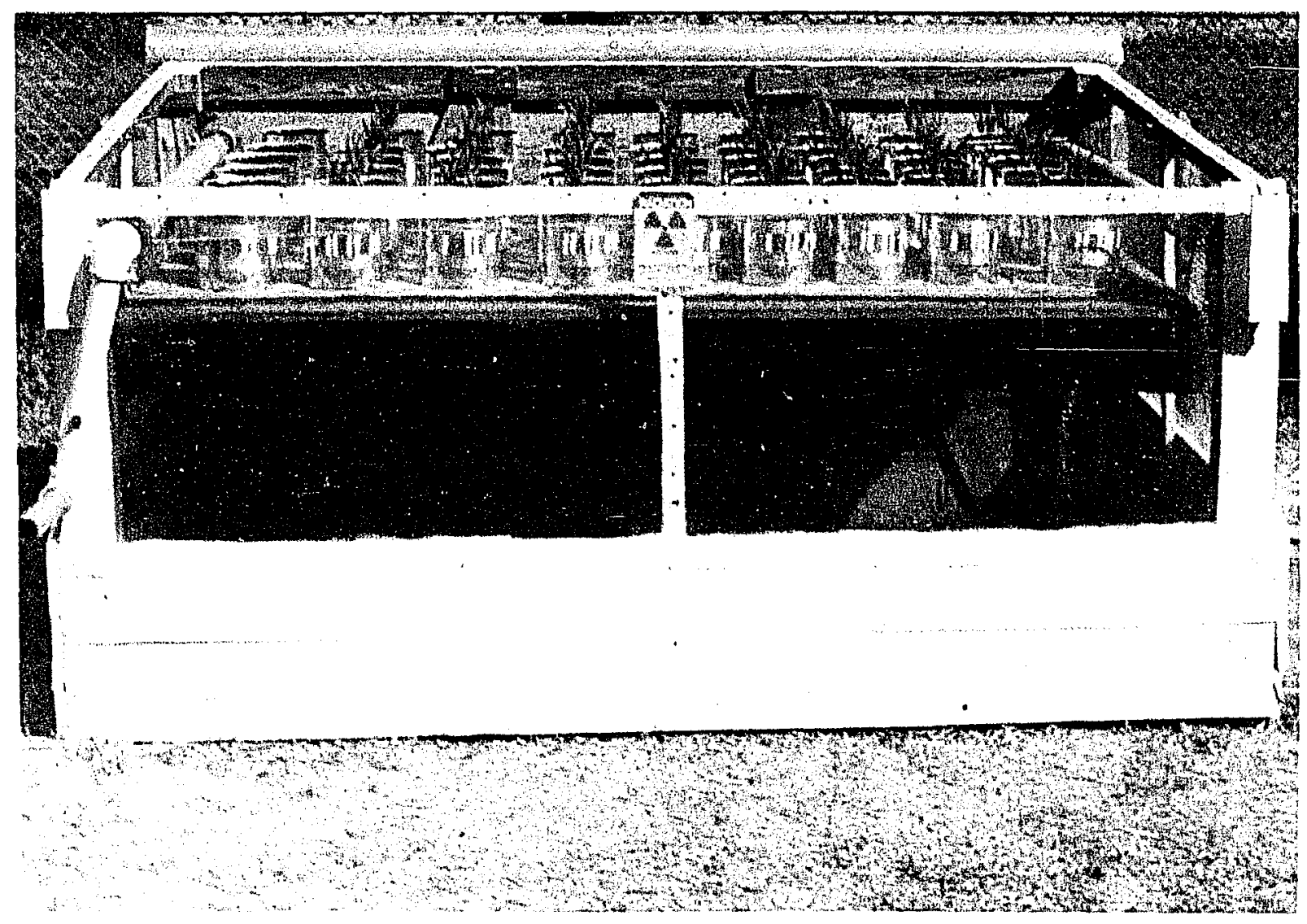

Plate 2.m Photograph of the cold frame with the elevator platform in its top-most position. 


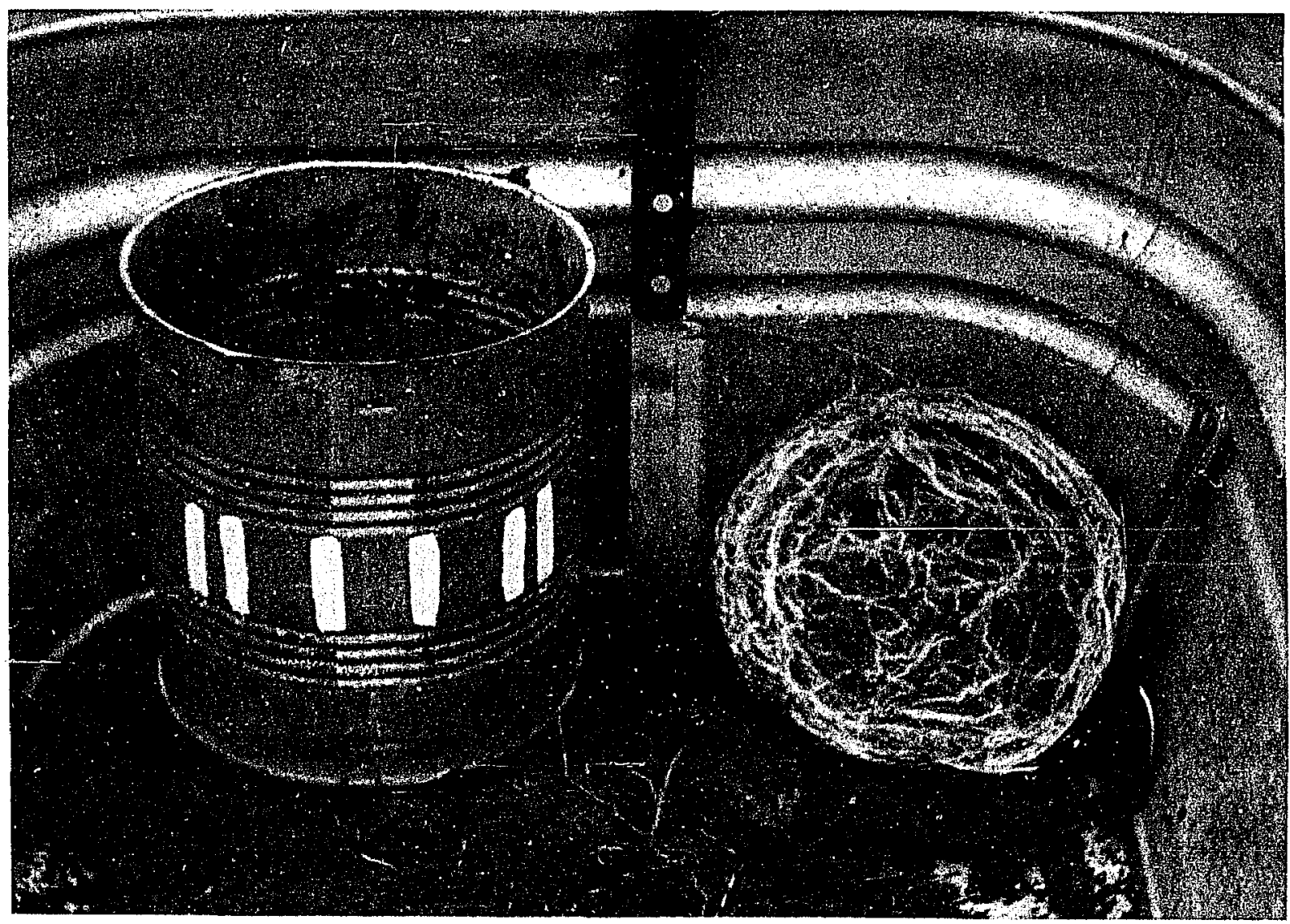

Plate 3.- Photograph of a tub used to wash the soil free from the roots at each harvest period. 
hand in a tub filled to approximately two-thirds of its capacity with water. The roots were then collected on an 18-mesh sieve by pouring the water in which the roots wore suspended over the sieve. The settled soil and roots trapped by settled soil were suspended again and the previous step of agitation and root collection was repeated. Approximately 10 washings in this manner were required to separate the roots from the soll. In collecting the roots, much organic matter was also obtained. Approximately 10 washings were required to separate the roots from the organle matter and small adhering soll particles. Roots from soil samples which were taken previous to the general separation of roots from soil were removed by use of a spatula and tweezers. These roots were placed with other roots collected from the same pot for drying and weighing.

Both the tops and the roots were dried in an oven for 4 hours at $70^{\circ} \mathrm{C}$ and 4 hours at $100^{\circ} \mathrm{C}$. Then after cooling in a dessicator they were welghed and the dry welght of each recorded. The dried tops and roots were ground to pass 0.027 inch openings of the screen of a homoloid mill. The plant materials were then redried for a short period of time and placed in air-tight containers.

Soil samples were taken at each sampling perlod from each of the 12 containers in which plants grew and also from the 6 containers which were not planted. Composite samples were taken from the mixed treatments. In the case of the 12-12-12-banded treatment, soil samples were taken in the fertilizer band, I inch below the fertilizer band and from the remainder of the soil further than 1 Inch from the fertilizer band. The 
samples from the 12-12-12-banded treatment were used to determine the approximate degree of phosphorus movement in the soil by radioactivity determinations. The sample taken at each harvest poriod from the 12-0-12-banded treatment was taken from soil further than 1 inch from the fertilizer band. All soil samples were air dried and then placed In air-tight containers. Moisture determinations were made on the soil samples and all results of determinations from the soll samples were corrected to oven-dry bases.

For the determination of fertilizer phosphorus obtained by the plants, standards of 0.25 gram each were welghed into glass planchets I.6 inches in diameter and 0.8 inch in helght. The bottom of exch planchet was flat. In the preparation of these standards, the amounts of radioactive pulverulent $12-12-12$ and the amounts of non-radioactive oat plant material which were thoroughly mixed together for the preparation of standard curve for radioactivity are shown below in tabular form:

\begin{tabular}{cccc}
\hline $\begin{array}{c}\text { Planchet } \\
\text { number }\end{array}$ & $\begin{array}{c}12-12-12 \\
\mathrm{~g} \cdot / \text { planchet }\end{array}$ & $\begin{array}{c}\text { Phosphorus } \\
\mathrm{mg} \cdot / \text { planchet }\end{array}$ & $\begin{array}{c}\text { Non-radioactive plant } \\
\text { material g./planchet }\end{array}$ \\
\hline 1 & 0.0093 & 0.500 & 0.2407 \\
2 & 0.0116 & 0.625 & 0.2384 \\
3 & 0.0139 & 0.750 & 0.2361 \\
4 & 0.0162 & 0.875 & 0.2338 \\
5 & 0.0186 & 1.000 & 0.2314 \\
6 & 0.0209 & 1.125 & 0.2291 \\
7 & 0.0231 & 1.250 & 0.2269 \\
8 & 0.0254 & 1.375 & 0.2246 \\
\hline
\end{tabular}

The mixture of 12-12-12 and plant material uniformly covered the bottom in each planchet to an approximate depth of 0.2 inch. Activity of each standard was determinod and the data was plotted on graph paper. A 
curve was constructed through the points on the graph. An example of calibration curves used for the determination of radioactive phosphorus in plant samples collected at the 4, 8, and 12-woek periods following planting appears as Figure 1.

Since some information was needed on possible sources of error in using calibration curves constructed from standards, the effects of thickness and area of standards and of care of standards in handling on results obtained were studied. Results of activity determinations where area of standard was reduced to as low as 50 per cent of normal value and where thickness of standard was increased to as much as 200 per cent of normal value showed deviations reaching to as high as from about 0.5 per cent less to about 1.5 per cent greater than results obtained with sample in the normal position. It was concluded that some of these results were due to chance and that most of the positive derim ations which exceeded the ebsolute value of the negative deviations were due to proximity of the sample to the window of the Geiger tube. Results of radioactivity determinations when the planchet containIng the standard was dropped several times to a bench top from a height of 1 inch never deviated more than 0.5 per cent from results of radioactivity obtained when standard sample was in the normal position and undisturbed. Results of about half of the determinations were greater and results of about half of the determinations were less than results obtained with undisturbed sample. This indicated that deviations were due to chance and not due to a tendancy for the ground plant material and fertilizer to separate into different horizons. 


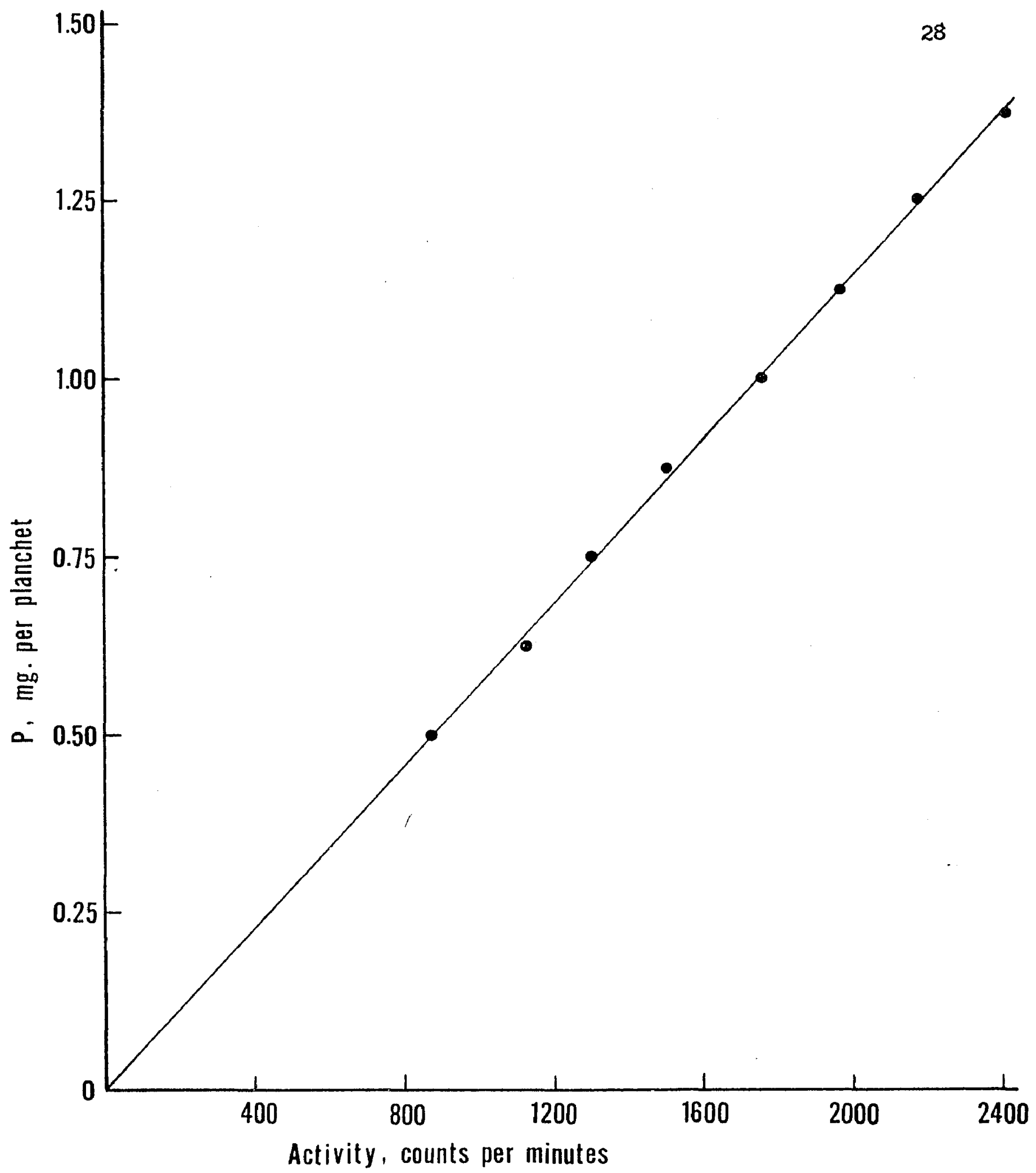

Figure 1.m Example of calibration ourve for determining amounts of radioactive phosphorus in samples. 
Radioactivity of 0.25 gram plant samples of plant tops and of roots was determined within a 10-dey perlod following sampling at 4 , 8 and 12 weeks after date of planting. These samples were taken from plant materials ground to pass 0.027 inch screen openings and were placed in the planchets in the same geometric arrangement as standards.

A Geiger-Miller 64 scaler equipped with an end-window Gelger tube housed in a lead-walled sample receiver was used to determine the number of beta emissions passing through the window of the Geiger tube. The beta emitter was $\mathrm{P} 32$ which has a half-life period of 14.3 days. The average energy of beta particles emitted by $\mathrm{P}^{32}$ is 1.712 millions of electron volts. No corrections were considered to be necessary for selfabsorption since standerds and samples were 1dentical in thickness and area (12). The curve plotted from data from the standards was a straight line which also indicated that no self-absorption was actually occurring.

No corrections for coincidence loss were applied during this experiment since coincidence corrections may usually be neglected at counting rates lower than 10,000 counts per minute (12). In this exper1ment the highest net activity determined for standards and for plant samples was about 2400 counts per minute. Net activity expressed in counts per unit time is the total counting rate minus background counting rate.

Length of count of samples was dictated by standard deviation value desired for acceptable accuracy. Standard deviation was calculated from the following equation (12): 


$$
\begin{aligned}
& \text { Standard deviation of } \\
& \text { sample counting rate }
\end{aligned}=\left[\frac{\mathrm{C}_{\mathrm{S}}}{\mathrm{T}_{\mathrm{B}}^{2}}+\frac{\mathrm{C}_{\mathrm{b}}}{\mathrm{T}_{\mathrm{b}}^{2}}\right]^{1 / 2}
$$

where $C_{s}=$ total counts for sample in time $T_{s} ; C_{b}=$ total counts for background in time $\mathrm{T}_{\mathrm{b}}$.

Net counts above 80 per minute were made for a length of time adequate to reduce the standard deviation of counting rate to 1 per cent. More than 80 net counts per minute were obtained for all samples and all standards used for the 4-week and 8-week harvest periods. Standard deviaction values for net rates of 20 counts per minute ranged to as high as 3 per cent in the cases of some samples and standards determined following the 12-week harvest. This involved counting time up to 3 hours per sample. The background throughout the experiment was normally between 15 and 25 counts per minute.

At the times of counting samples from the 8-week and 12-week harvests, only the highest two standards were used for determination of points from which a straight-line curve could be constructed. This reduced the time required for determinations and for counting rate corrections. Counting rate corrections were made by use of the following equation (24):

$$
\frac{d N}{d t}=\left(\frac{d N}{d t}\right)_{t=0} \theta^{-0.693(t / h)}
$$

where $\frac{d N}{d t}=$ counting rate at $t i m e t ;\left(\frac{d N}{d t}\right)_{t=0}=$ counting rate at time $t=0$; $h=$ half-life period.

AIl counting rates which were determined at a mean time more than 6 hours removed from that at whlch the data for the standard curve was obtalned were corrected. 
No strictIy quantitative method for determination of radioactivity In the soll was worked out. However, activity of l-gram semples of soll was recorded in order to ascertain the approximate aegree of phosphorus movement in the soil. These soil activity determinations were made by placing the soil samples in the same type planchets as those used for plant activity determinations.

The same 0.25 gram samples used in the determination of fertilizer phosphorus absorption by plants were used to determine total phosphorus in the plant tissue. The samples were wet ashed by digesting in $10 \mathrm{ml}$. of concentrated nitric acid for 48 hours. The samples were then heated at low temperature on a hot plate to approximately $90^{\circ} \mathrm{C}$. After the plant material had digested, $5 \mathrm{ml}$. of 60 per cent perchloric acid was added to es.ch sample and heat was applied until salts appeared. A 1:1 mixture of perchlortc acid and nitric acid was added and the material was again brought to dryness at a low temperature on a hot plate. This was repeated as necessary until a clear color appeared and salts were white. The salts in each sample were then taken up in $10 \mathrm{ml}$. of $5 \mathrm{~N}$ hydrochloric acid. Each sample was then heated, $10 \mathrm{ml}$. of hot water were added, and the solution was immediately filtered through Whatman 42 filter paper into a $100 \mathrm{ml}$. volumetric flask. Flasks were then brought to volume. A $5 \mathrm{ml}$. sample of each $100 \mathrm{ml}$. of solution was placed into a $50 \mathrm{ml}$. volumetric fiask or dilutions as indicated by experience were made. The $5 \mathrm{ml}$. sample from the original $100 \mathrm{ml}$. of solution or from a dilution from that solution was diluted to $25 \mathrm{ml}$. and $4 \mathrm{ml}$. of a sodium metabisulfite solution was added to reduce ferric iron present. When I 
hour had lapsed following the introduction of sodium metablsulfite, $10 \mathrm{ml}$. of Truog's ammonium molybdate sulfuric acid solution were added. Then 3 drops of a stannous chloride solution were added and the resulting solution was brought to volume. Color was allowed to develop for 10 minutes following introduction of the ammonium molybdate and the stannous chloride solutions. Readings were then made on a Bechman D. U. Spectrophotometer.

Standards were prepared at each period of determinations. In each standard, $5 \mathrm{ml}$. of a solution containing a known amount of phosphorus in the form of $\mathrm{KH}_{2} \mathrm{PO}_{4}$ were placed in a $50 \mathrm{ml}$. volumetric flask. To each flask the same reagents were added in the same amounts as were added to solutions in flasks of the unknowns. Colors were developed in the same manner as for the unknowns. The values obtained from the sprectrophotometric readings were plotted on graph paper and a standard curve was constructed through the points plotted.

Soil samples were analyzed for soluble phosphorus by use of 3 extractants, $0.1 \mathrm{~N} \mathrm{HCI}+0.03 \mathrm{~N} \mathrm{NH}_{4} \mathrm{~F}, 0.025 \mathrm{~N} \mathrm{HCl}+0.03 \mathrm{~N} \mathrm{NH}$ N HCl. For this purpose, I gram of soil and $40 \mathrm{ml}$. of extracting solution were used in each analysis. Hence, 8. soil:extractant ratio of 1:40 was employed. After the soil was placed in the extractant, the mixture was shaken for 1 minute and then filtered through Whatman 42 filter paper. A $25 \mathrm{ml}$. aliquot from the filtrate was then placed in a $50 \mathrm{ml}$. volumetric flask. Ferric tron was reduced and color was developed in the same manner as in the case of plant samples. A standard curve was constructed with each extractant by developing standards similar to those developed 
for the plant material with the exception that, by use of $25 \mathrm{ml}$. of the proper extractant in standards, ions which possibly interfere with color development were held at about the same concentration in the standards as in the samples.

Film badge service was used throughout this experiment when working with radioactive materials. A survey meter equipped with a Geiger tube on an extension cord was used to monitor each area in which radioactivity was suspected. All radioactive plant and soil materials used throughout the experiment were kept under close observation. After the experiment had been completed and after about 17 half-life periods of the $\mathrm{p}^{32}$ had passed, all radioactive material was placed in a hole and covered with soil to a depth of 3 feet in an isolated ares of the University of Houston Demonstration Farm, Pasadena, Texas.

Yields in forage, in straw and in grain obtalned in the study were analyzed by analysis of variance method (91). The least difference necessary for significance between mean yields was computed.

Yields of oats and results from the analyses of soil and plant tissue are given in tables and figures in the following section. 
Results and Discussion

In Table I, which contains data representing the 4-week harvest, it may be observed that the average yield of tops of oat plants which grew in the 12-12-12 treatments was markedly higher than the average yield of tops of oat plants which grew in the 12-0-12 treatments. This difference was statistlcally highly significant. The data are shown graphically in Figure 2. A photograph of the plants as they appeared on the harvest date is shown as Plate 40 The yleld differences may be attributed primarily to the fertilizer phosphorus. The magnitude of the differences may be attributed largely to the extremely low amount of available phosphorus in the soll and to the relatively high amount of fertilizer phosphorus applied. The difference between yleld of tops of plants which grew in the 12-12-12-banded treatment and yield of tops of plants which grew in the 12-12-12-mixed treatment was statistically significant. It may be noted that the yield from the former treatment was over one-tenth greater than that of the latter treatment. This may be accounted for by the proximity of the fertilizer to the oat seeds and the effect of this concentrated band of fertilizer on the early and rapid development of both the roots and tops of the plants. The difference in top yields of the 12-0-12-banded and the 12-0-12-mixed treatments was not statistically significant. The top growth of the plants receiving the 12-0-12-banded treatment, eventhough limited, was about one-third greater than that of plants receiving the 12-0-12-mixed 
Table 1.- Effects of soil phosphorus, fertilizer phosphorus and placement on the yield of oats and the soil phosphorus and fertilizer phosphorus in the oat plants harvested 4 weeis after date of plenting.

\begin{tabular}{|c|c|c|c|c|c|c|}
\hline Fertilizer & $\begin{array}{l}\text { Method of } \\
\text { goolication }\end{array}$ & $\begin{array}{l}\text { Dry wt. } \\
\text { g./pot }\end{array}$ & $\underset{\substack{\text { Soil } \\
0}}{ } P$ & Fertilizer $\mathrm{P}$ & $\begin{array}{c}\text { Total } \\
\frac{1}{2}\end{array}$ & $\begin{array}{c}\text { Applied } \bar{P} \\
\text { absorbed } \\
\theta\end{array}$ \\
\hline
\end{tabular}

Tops of plants

$\begin{array}{lllllll}12-0-12 & \text { Banded } & 0.59 & 0.091 & - & 0.091 & - \\ 1 " \| & \text { Mixed } & 0.45 & 0.093 & - & 0.093 & - \\ 12=12-12 & \text { Banded } & 2.50 & 0.010 & 0.426 & 0.436 & 10.62 \\ 11 & \text { Mixed } & 2.25 & 0.033 & 0.228 & 0.261 & 5.11\end{array}$

Roots of plants

$\begin{array}{lllllll}12-0-12 & \text { Banded } & 0.23 & 0.090 & - & 0.090 & - \\ \text { " " } & \text { Mixed } & 0.20 & 0.069 & - & 0.069 & - \\ 12-12-12 & \text { Banded } & 1.15 & 0.002 & 0.131 & 0.133 & 1.50 \\ \text { " " } & \text { Hixed } & 1.12 & 0.004 & 0.130 & 0.134 & 1.45\end{array}$




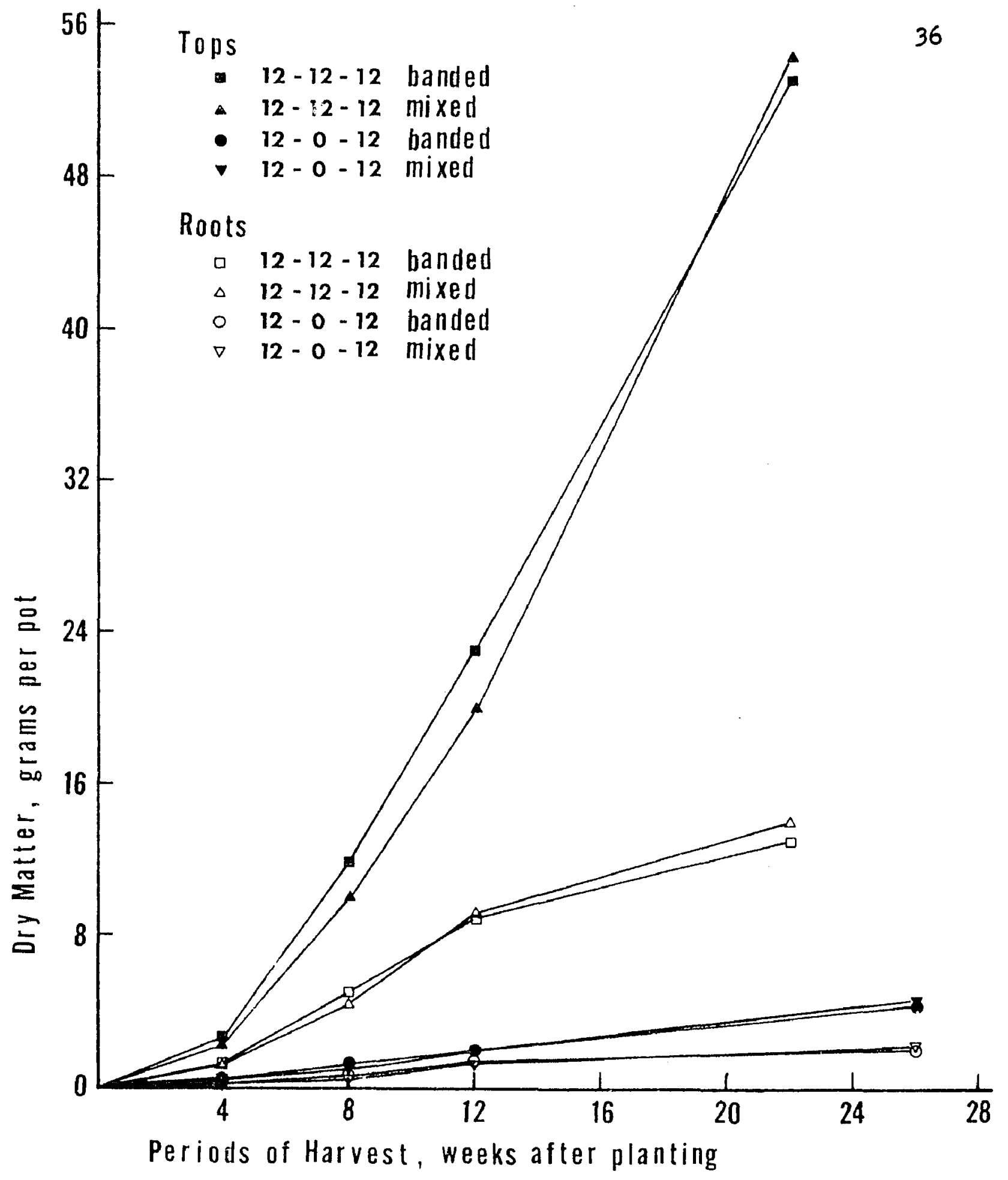

Figure 2.- Effects of soil phosphorus, fertilizer phosphorus and placement on yield of oats. 


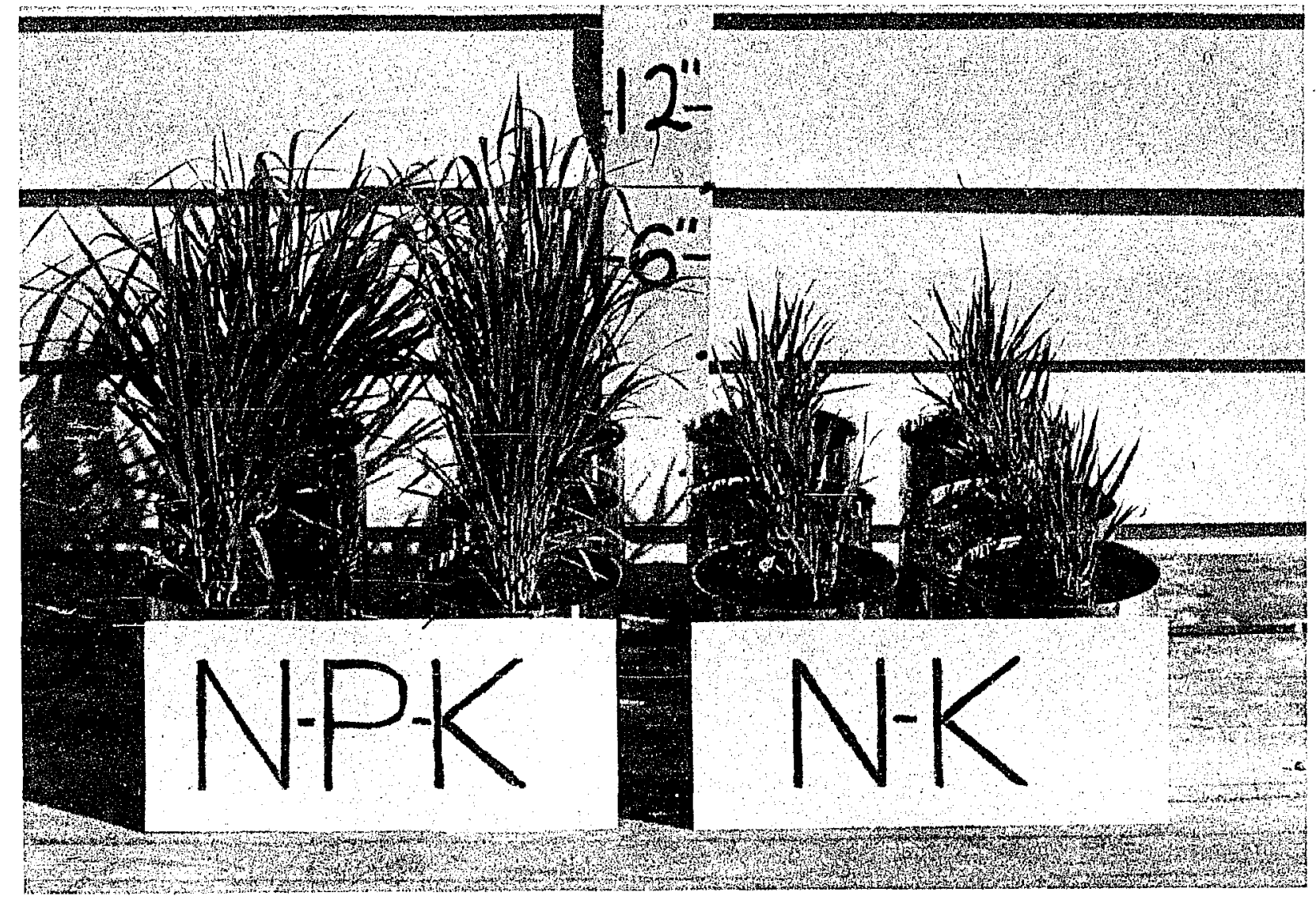

Plate 4.- Photograph of the oat plants harvested at the 4-week harvest period. 
treatment. This indicates some initial advantage of the banded treatment over the mixed treatment. The root yields from the various treatments were related approximately as the top yields were related. No statistical treatment was given, however, to root-yleld data.

From Table 1 and Elgure 3 it may be noted that the per cent of total phosphorus in the tops of the plants receiving the 12-12-12banded treatment was over 4 times that of the 12-0-12-banded treatment and that the per cent of total phosphorus in the tops of the plants receiving the 12-12-12-mixed treatment was almost 3 times that of the 12-0-12-mixed treatment. These great differences in the phosphorus content of the oat plants may be attributed to the differences in phosphorus available to the plants. The per cent of total phosphorus In the tops of the plants recelving the 12-12-12-banded treatment was considerably greater than that of the plants receiving the 12-12-12mixed treatment. This difference may also be attributad to the differences in phosphorus available to the plants. In this case availability is related to closeness of the fertilizer to the young developing roots and it may also be related to the conditions that Lake Charles clay has a high phosphorus-fixing capacity and that the likelihood of a high amount of phosphorus applied in the band remaining avallable is greater than in the case of phosphorus mixed with the soil. In fact, the phosphorus applied in the band practically all remained in the band, as Indicated by data in Table 8, and probably almost all remained in the same chemical form as when applied. The per cent of total phosphorus in the roots which grew in the 12-12-12-banded treatment was practically 


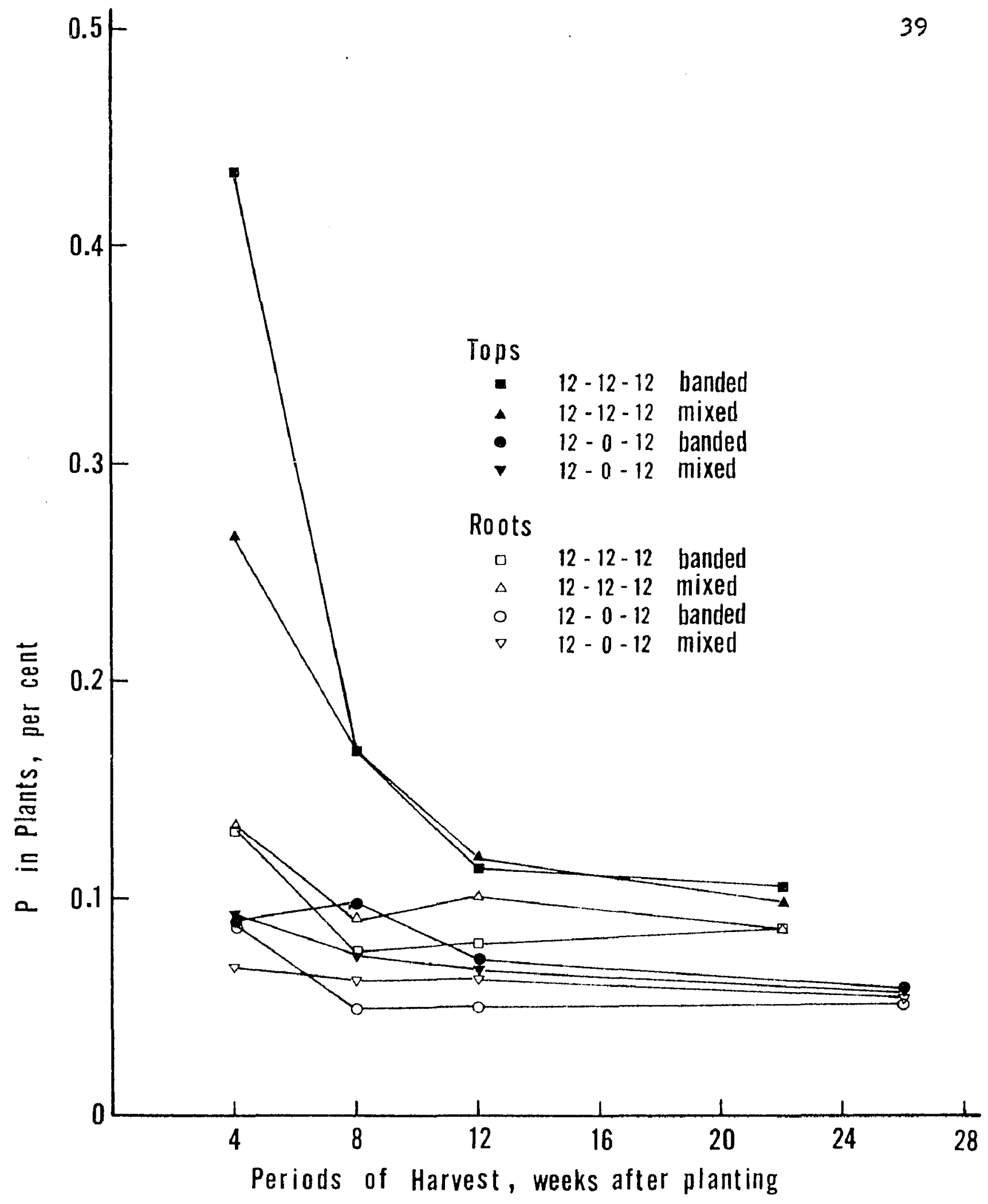

Figure 3.- Effects of soil phosphorus, fertilizer phosphorus and placement on phosphorus content of oats. 
equal to that of the roots which grew in the 12-12-12-mixed treatment. Since the amount of phosphorus in the tops of the plants which grew In the 12-12-12-banded treatment was considerably higher than the amount of phosphorus in the tops of the plants which grew in the 12-12-12-mixed treatment, it is evident that translocation of phosphorus from the roots of plants treated with 12-12-12 which was banded in the soil occurred at a more rapid rate than translocation of phosphorus from the roots of plants treated with 12-12-12 which was mixed with the soil. The per cent of total phosphorus in the roots which grew in the 12-0-12-banded treatment, eventhough low, was definitely higher than that of the roots which grew in the 12-0-12-mixed treatment. This Indicates that the salts in the band influenced more phosphorus to enter the roots than was influenced by the salts in the 12-0-12-mixed treatment. Since a high proportion of the roots in the 12-0-12-banded treatment which had developed at the time of this harvest were concentrated in and near the fertilizer band, it appears that the major portion of the soil phosphorus which entered the plants came from in and near the fertilizer band. Roots of the plants which grew in the 12-0-12-mixed treatment developed in a similar zone of the soil but extracted less soil phosphorus. Since the phosphorus content of roots which grew in the 12-0-12 treatments approached the phosphorus content of the tops of plants whioh the roots supported, it appears that roots require a relatively higher amount of the phosphorus absorbed for their own development than in cases when phosphorus is not so limited in the soil. 
It may be observed from data in lable 1 that the fertilizer phosphorus in the tops harvested from the 12-12-12-banded and the 12-12-12-mixed treatments was in approximately the same ratio as the total phosphorus in the tops from the two treatments. In these two treatments, the soil phosphorus contributed a very small portion to the total phosphorus. Much more soil phosphorus, however, was in the tops of plants which grew in the 12-12-12-mixed treatment then was in the tops of plants which grew in the 12-12-12-banded treatment. The plants which grew in the 12-12-12-inixed treatment were net in contact with such a large supply of phosphorus as were those which grew in the 12-12-12-banded treatment and they absorbed more soil phosphorus. This may be explained by considering the phosphorus requirement of the plants during growth in the 12-12-12-mixed treatment. These plants were growing almost as fast as the plants in the 12-12-12-banded treatment. The applied phosphorus had apparentily become fixea to a considerable degree. The expanded root system was in surface contact with practically as much soll as was the root system in the 12-12-12banded treatment but did not have nearly as much fertilizer phosphorus on which to feed. Since there was a high phosphorus requirements and since there was root-soil contact comparable to that in the 12-12-12banded treatment, relatively more soil phosphorus was absorbed. The amounts of fertilizer phosphorus and soil phosphorus absorbed are shown graphically in Figure 4 .

Table 1 shows practically no difference between the per cent fertilizer phosphorus or of soil phosphorus in the roots of plants 


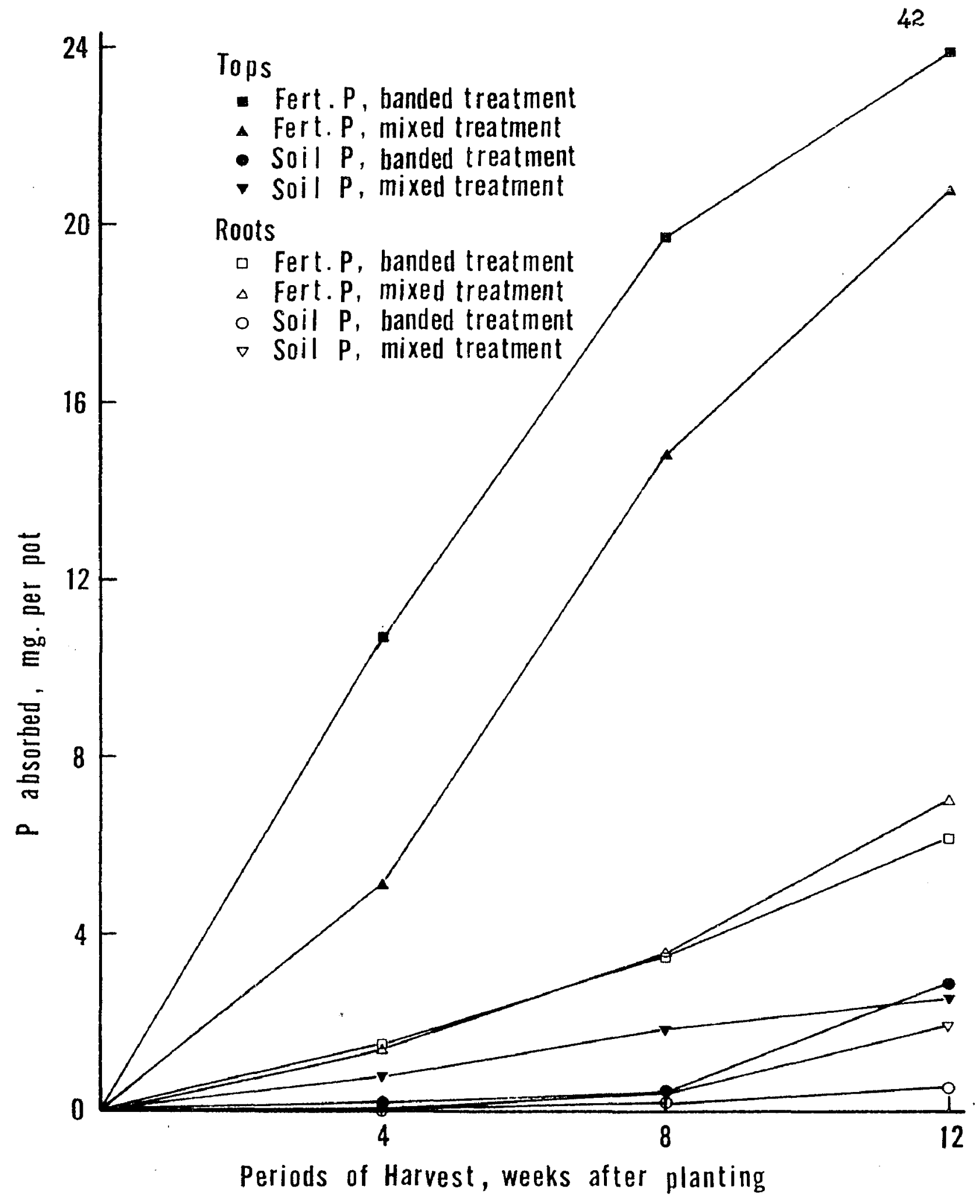

Figure 4.- Effects of banding and of mixing 12-12-12 fertilizer on the uptake of soll and fertilizer phosphorus by oats. 
which grew in the soil in which 12-12-12 was banded as compared to the roots from the soil in which $12-12-12$ was mixed.

Data in Table 1 show that the amount of applied phosphorus absorbed by the plants which grew in the soil in which 12-12-12 was banded was almost twice that of the plants which grew in soil in which 12-12-12 was mixed. Since fertilizer phosphorus contributed most of the phosphorus absorbed by the plants, the explanation given above for the difference in total phosphorus for these two treatments also applies here. In Table 2, which contains yield and phosphorus data of plants harvested at the 8-week harvest, it may be noted that the average yield of tops from the 12-12-12 treatments was over 10 times the average yiela of tops from the two 12-0-12 treatments. This difference was statistically highly significant. The yield data are shown graphically in Flgure 2. A photograph of the plants as they appeared on the harvest date appesrs as Plate 5. The yield differences between 12-12-12 treatments and $12-0-12$ treatments may be attributed to the fertilizer phosphorus. The yield of tops of plants which grew in the soil in which 12-12-12 was banded was significantly higher than that of plants which grew in the soil in which 12-12-12 was mixed. An explanation for this difference is given above in the discussion of the 4-week harvest. There was no significant difference between the yield of tops of plants grown in the 12-0-12-banded treatment and the yield of tops of plants grow in the 12-0-12-mixed treatment. The root yields from the various treatments were in approximately the same order as the top yields as shown by data in Table 2 . 
Table 2.- Effects of soil phosphorus, fertilizer phosphorus and placement on the yieId of oats and the soil phosphorus and fertilizer phosphorus in the oat plants harvested 8 weeks aiter date of planting.

\begin{tabular}{|c|c|c|c|c|c|c|}
\hline Fertilizer & $\begin{array}{l}\text { Method of } \\
\text { application }\end{array}$ & $\begin{array}{l}\text { Dry wt. } \\
\text { E./pot }\end{array}$ & Soil $p$ & $\underset{5}{\text { Fertilizer } P}$ & $\operatorname{Tota} 1 P$ & $\begin{array}{l}\text { Aoplied P } \\
\text { absorbed }\end{array}$ \\
\hline
\end{tabular}

Tops of plants

$\begin{array}{llrlclc}12-0-12 & \text { Banded } & 1.17 & 0.098 & - & 0.098 & - \\ \|"\| & \text { Mixed } & 0.92 & 0.073 & - & 0.073 & - \\ 12-12-12 & \text { Banded } & 11.96 & 0.004 & 0.165 & 0.169 & 19.67 \\ \|"\| & \text { Iixed } & 9.94 & 0.020 & 0.149 & 0.169 & 14.77\end{array}$

Roots of plants

\begin{tabular}{lllllll}
$12-0-12$ & Banded & 0.63 & 0.048 & - & 0.048 & - \\
$\|"\|$ & Kixed & 0.50 & 0.061 & - & 0.061 & - \\
$12-12-12$ & Banded & 4.97 & 0.004 & 0.069 & 0.073 & 3.42 \\
$" 1 "$ & Kixed & 4.34 & 0.009 & 0.081 & 0.090 & 3.50 \\
\hline
\end{tabular}




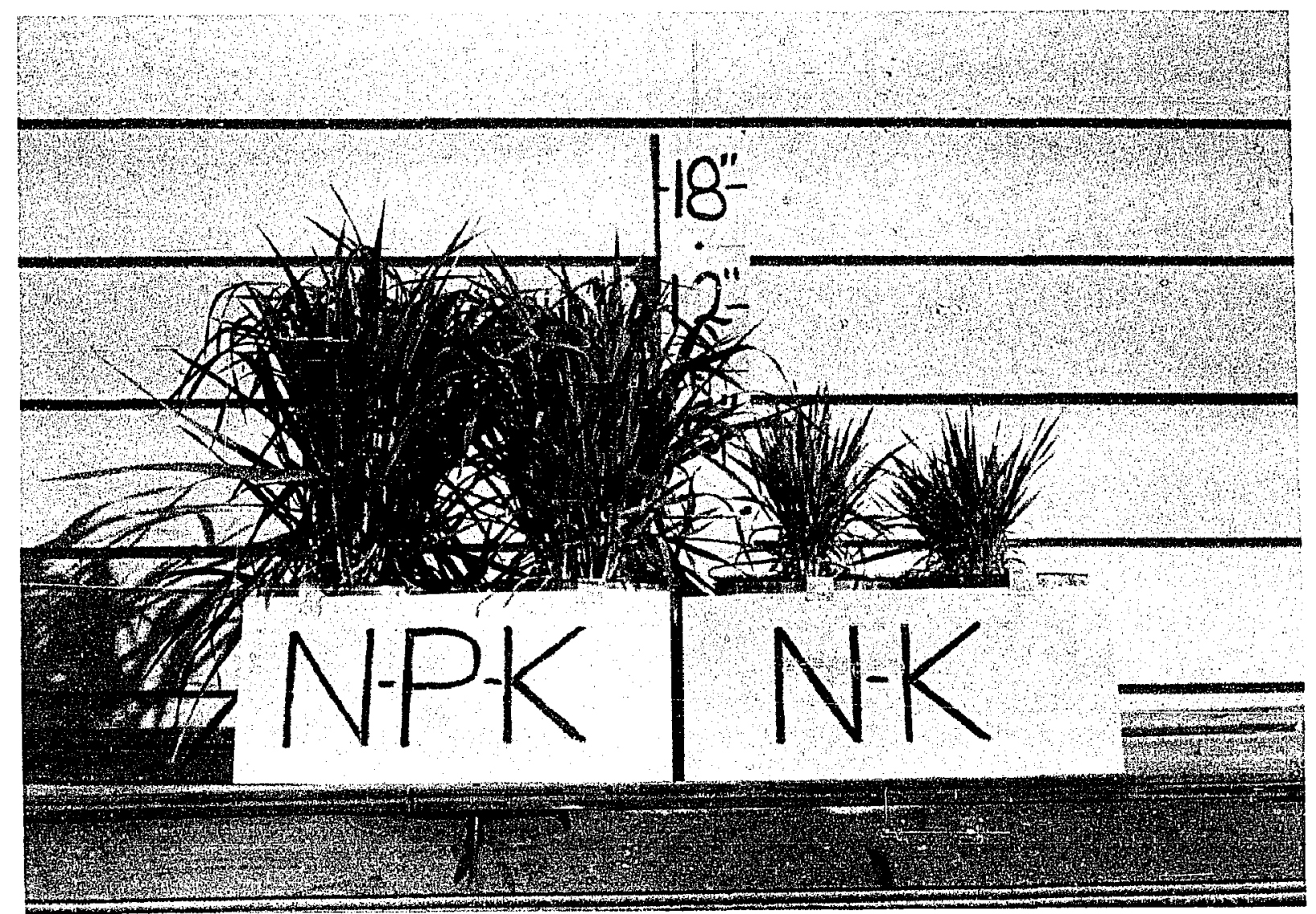

Plate 5.- Photograph of the oat plants harvested at the 8-week harvest period. 
The data in Table 2 and Figure 3 show that the per cent of total phosphorus in the tops of the plants which grew in soll in which 12-12-12 was banded dropped to the same value as that of tops of plants which grew in soil in which $12-12-12$ was mixed. The latter value for the 8-week harvest had dropped to about two-thirds of the value of the same treatment at the 4-week harvest. These two percentage values were still much greater than those for tops of plants receiving the 12-0-12banded and 12-0-12-mixed treatments. The differences in the amount of phosphorus in the plants receiving the 12-12-12 treatments and the 12-0-12 treatments may be attributed to fertilizer phosphorus. According to Morrison (66), a 1000-pound wintering pregnant beef cow had a daily phosphorus requirement of 0.037 pound and a daily dry matter requirement of 14.2 to 20.0 pounds. Since the two treatments involving the 12-12-12 fertilizer had the same per cent of total phosphorus, 0.169 , a quantity of oats from either treatment equivalent to 17.1 pounds of ary matter would contain 0.029 pound of phosphorus or about eight-tenths of the daily requirement of a 1000-pound wintering pregnant beef cow. It can be deduced from values in Figure 3 that a similar quantity of oats from the 12-12-12-mixed treatment would have fully met the daily phosphorus requirement in question at the six-week stage of growth. At the six-woek stage of growth, a like quantity of oats which received the 12-12-12-banded treatment would have provided considerably more than the daily phosphorus requirement of a 1000-pound wintering pregnant beef cow. Oats used for winter grazing in the Texas Gulf Coast Area are normally grazed the first time 
about six weeks after the date of planting. They are then normally top-dressed with a nitrogen fertilizer to insure rapid recovery and increased growth. Figure 3 indicates the need of a fertilizer that also contains phosphorus in order that the phosphorus content of the plants will remain at a relatively high level and give a yield above that which would be obtained with nitrogen alone. Riewe and Smith (83), in a pasture fertilization experiment at Angleton, Texas, on Lake Charles clay soil, found surface application of phosphorus to be satisfactory for established pastures.

The total phosphorus in the roots of oats from the 4 treatments at the 8-week harvest, as shown in Table 2, bear the same relationships to the total phosphorus in the tops of plants as at the 4-week harvest. The per cent of phosphorus was lower in both the tops and roots from all treatments at the 8 -week harvest. The values were approximately two-thirds of those for the 4 -week harvest. The general reduction of the per cent of phosphorus in tops and in roots below the 4-week values appears to be associated with the degree of maturity of the plants.

Calculations based on data in Table 2 reveal that approximately one-fourth more of the applied phosphorus was absorbed by the plants which grew in the soil in which $12-12-12$ was banded than was absorbed by the plants which grew in the soil in which 12-12-12 was mixed. Calculations using total yleld of tops and roots show that plants which grew in soil recelving the 12-12-12-mixed treatment absorbed over 3 times more soil phosphorus than did the plants which grew in 
the soil receiving the 12-12-12-banded treatment. The amounts of fertilizer phosphorus and of soil phosphorus absorbed are shown graphically in Figure 4.

Table 3 contains yield and phosphorus data concerning plants harvesied at the 12-week harvest period. The yield data are show graphically in Figure 2. Plate 6 is a photograph of the plants taken at the 12-week harvest period. The 2 rows of plants at the left, which were treated with 12-12-12 fertilizer, had developed nitrogen deficiency symptoms. The average of the top yields of the 12-12-12. treatments was over 11 times the average of the top yields of the 12-0-12 treatments. These yield differences may be attributed to the fertilizer phosphorus. Yield of tops of plants which grew in the 12-12-12-banded treatment was significantly higher than that of the 12-12-12-mixed treatment. There was no significant difference in yield of tops of plants which were harvested from the 12-0-12-banded treatment and from the 12-0-12-mixed treatment. The root yields were related to treatment approximately as the top yields were related.

The data in Table 3 and Figure 3 show that the phosphorus content of the tops of plants which grew in soil in which 12-12-12 was banded dropped to 0.115 per cent which is about two-thirds of the per cent of phosphorus in the tops of the plants which grew in the same treatment which was harvested at the 8-week period. Approximately the same amount of reduction in per cent of phosphorus is noted for the 12-12-12mixed treatment. These reductions in the per cent of phosphorus in tops at the 12-week harvest below the 8 -week values can be associated with 
Table 3.- Effects of soil phosphorus, fertilizer phosphorus and placement on the yield of oats and the soil phosphorus and fertilizer phosphorus in the oat plants harvested 12 weeks after date of planting.

\begin{tabular}{|c|c|c|c|c|c|c|}
\hline Fertilizer & $\begin{array}{l}\text { Method of } \\
\text { application }\end{array}$ & $\begin{array}{l}\text { Dry wt. } \\
\text { g./pot }\end{array}$ & $\operatorname{Soil}_{7} P$ & $\underset{*}{\text { Fertilizer }} P$ & $\underset{: \mathbb{0}}{\operatorname{Total}} P$ & $\begin{array}{l}\text { kpolied } \\
\text { absorbed } \\
\text { of }\end{array}$ \\
\hline
\end{tabular}

Tops of plants

$\begin{array}{lllllll}12-0-12 & \text { Banded } & 1.95 & 0.072 & - & 0.072 & - \\ \| " \text { "Iixed } & 1.95 & 0.067 & - & 0.067 & - \\ 12-12-12 & \text { Banded } & 23.27 & 0.012 & 0.103 & 0.115 & 23.90 \\ \|"\| & \text { Hixed } & 19.73 & 0.013 & 0.105 & 0.118 & 20.65\end{array}$

Roots of plants

\begin{tabular}{|c|c|c|c|c|c|c|}
\hline $12-0-12$ & Banded & 1.38 & 0.050 & - & 0.050 & - \\
\hline$" n$ & Mixed & 1.30 & 0.062 & - & 0.062 & - \\
\hline $12-12-12$ & Banded & 8.88 & 0.005 & 0.074 & 0.079 & 6.55 \\
\hline " & Mixed & 8.96 & 0.022 & 0.079 & 0.101 & 7.06 \\
\hline
\end{tabular}




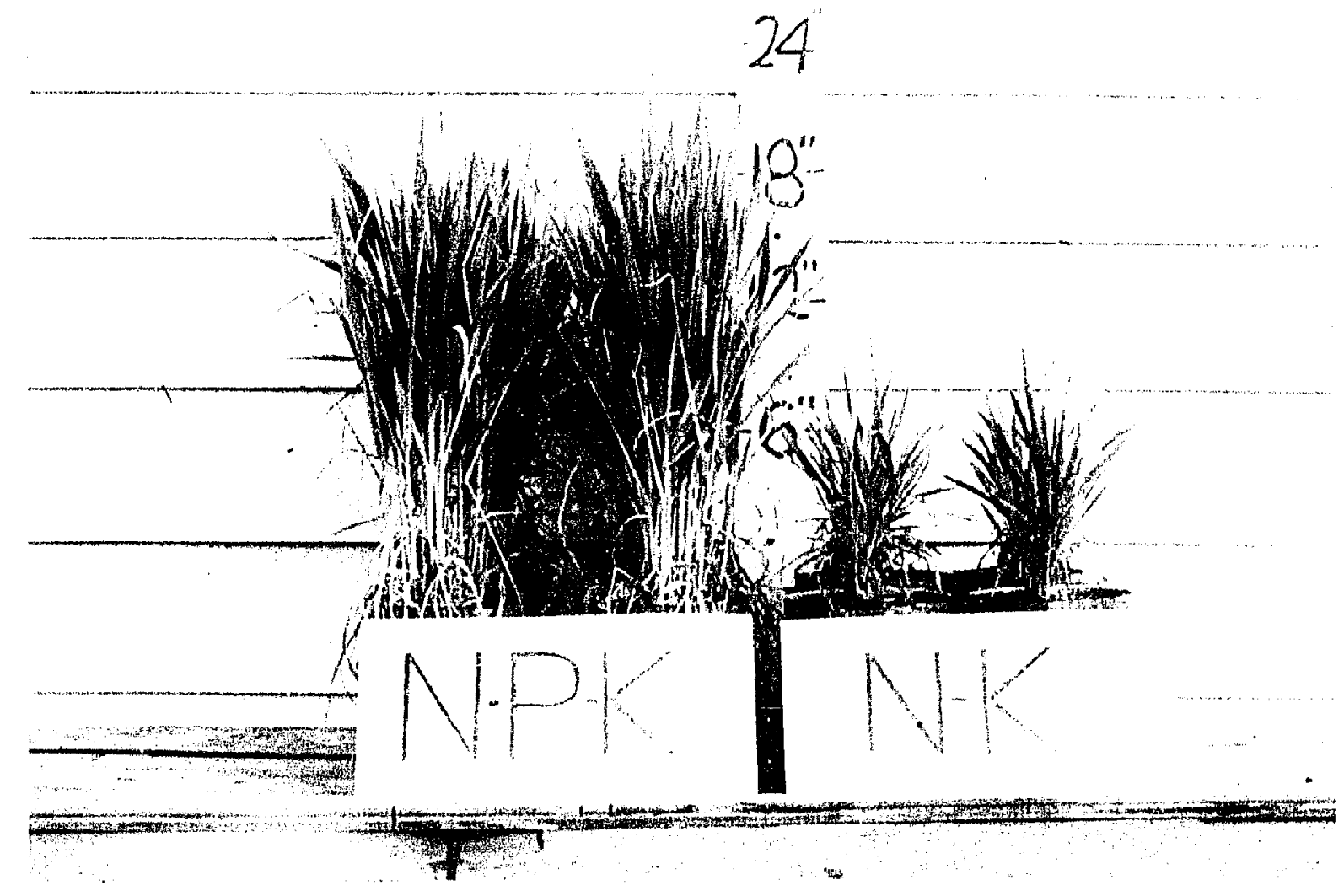

Plate 6.- Photograph of the oat plants hervested at the 12-week harvest period. 
the degree of maturity. The average of the per cent phosphorus in the tops of plants which grew in the $12-12-12$ treatments is about two-thirds higher than that of plants which grew in the $12-0-12$ treatments. This difference may be attributed to the fertilizer phosphorus. The average of the per cent of phosphorus in the roots of plants which were harvested from the 12-12-12 treatments is about one-half greater than that of roots of plants harvested from the 12-0-12 treatments. In the case of the 12-12-12 treatments, the values indicating the total phosphorus likely would have been different at the 12-week harvest had the plants not developed a nitrogen deficiency. There were no appreciable differences between the per cent of total phosphorus in the roots at the 12-week harvest as compared to the per cent of total phosphorus from the respective treatments at the 8-week harvest. As the plants approached maturity, the per cent of phosphorus in tops and in roots more nearly approached the same value.

Data in Table 3 show that, at the end of 12 weeks of growth, 30.45 per cent of the applied phosphorus had been absorbed by the plants which received the 12-12-12-banded treatment. The fertilizer phosphorus absorbed by plants treated with $12-12-12$ mixed in the soil was 27.71 per cent of the applied phosphorus. Calculations using total yield of tops and roots reveal that plants which grew in soil in which 12-12-12 was mixed absorbed almost one-half more soil phosphorus than did the plants which grew in the soll in which 12-12-12 was banded. The amounts of fertilizer phosphorus and soil phosphorus absorbed are shown graphically in Figure 4. 
Table 4 shows grain, straw and root yields at maturity. Figure 2 shows these values graphically. Plate 7 contains a photograph of the plants taken at the time of harvest of the plants which received the 12-12-12 treatments. The photograph clearly shows the difference in'stage of maturity of the oat plants. In Figure 2, the last yield of tops indicated for each treatment includes both straw and grain. Yield differences between grain and straw from the 12-12-12 treatments and grain and straw from the 12-0-12 treatments were statistically highly significant. There was no significant difference between grain yield or straw yield from the 12-12-12-banded and the grain yield or straw yield from the 12-12-12-mixed treatments.

From the jield data in Tables 1 through 4 and in Figure 2, it may be concluded that band placement of 12-12-12 fertilizer gave an increase in forage yield over mixing 12-12-12 fertilizer with the soil. It may also be concluded that either banding or mixing the fertilizer served equally weli for grain production.

The date on phosphorus content in Table 4 show that the per cent of totel phosphorus in the grain from the 12-12-12-banded and the 12-12-12-mixed treatments are practically equal. The average of the per cent of phosphorus in the grain harvested from the 12-12-12 treatments is about one-fourth greater than the average of the per cent of phosphorus in the grain harvested from the 12-0-12 treatments. The average of per cent of phosphorus in the straw harvested from the 12-12-12 treatments is about one-third higher than that of the straw harvested from the 12-0-12 treatments. The average of the per cent of 
Table 4.- Jffects of soil phosphorus, fertilizer phosphorus and placement on the yield of oats and the phosphorus content of oat plants harvested at maturity."

\begin{tabular}{|c|c|c|c|}
\hline Fertilizer & $\begin{array}{l}\text { Wethod of } \\
\text { application }\end{array}$ & $\begin{array}{l}\text { Dry wt: } \\
\text { g./pot }\end{array}$ & $\begin{array}{c}\text { Total F } \\
\%\end{array}$ \\
\hline \multicolumn{4}{|c|}{ Grain } \\
\hline $12-0-12$ & Banded & 0.37 & 0.274 \\
\hline\|\|$n$ & Mixed & 0.48 & 0.267 \\
\hline $12-12-12$ & Banded & 10.00 & 0.348 \\
\hline$\| " 17$ & Mixed & 9.86 & 0.347 \\
\hline
\end{tabular}

Stray

$\begin{array}{cccc}12-0-12 & \text { Banded } & 3.91 & 0.034 \\ 11 & \text { Nixed } & 4.14 & 0.034 \\ 12-12-12 & \text { Banded } & 42.96 & 0.048 \\ 11 & \text { Hixed } & 44.43 & 0.042\end{array}$

Roota

$\begin{array}{llrr}12-0-12 & \text { Banded } & 1.99 & 0.053 \\ " 1 " ~ & \text { Biixed } & 2.09 & 0.057 \\ 12-12-12 & \text { Banded } & 12.90 & 0.086 \\ 11 " 11 & \text { Mixed } & 13.90 & 0.087\end{array}$

* The plants treated with 12-0-12 were harvested 26 weeks after date of planting. The plants treated with 12-12-12 were harvested 22 weeks after date of planting.

** Dry weight in the case of the grain refers to air-dry weight. 


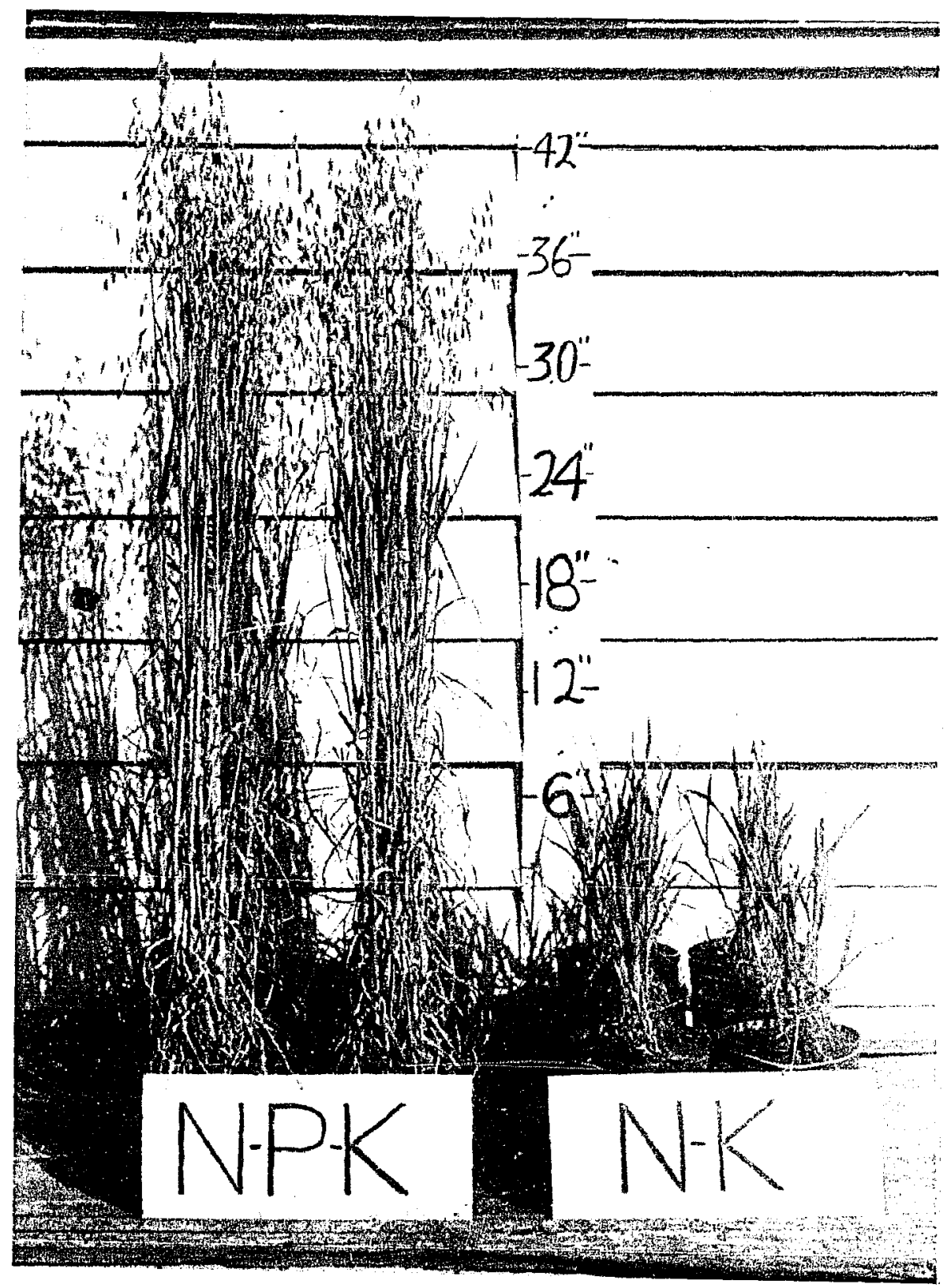

Plate 7.- Photograph of the oat plants harvested at maturity. The ripe oats at the left, treated with 12-12-12, were harvestod on the date of this photograph when 22 weeks old. The plants at the right, treated with $12-0-12$, were harvested when fully headed and ripe at 26 weeks of age. 
phosphorus in the roots harvested from the 12-12-12 treatments is over one-half more than the average of the per cert of phosphorus in the roots harvested from the $12-0-12$ treatments. The higher values for phosphorus in the grain, straw and roots of oats harvested from the 12-12-12 treatments, as compared to the values from the 12-0-12 treatments, may be attributed to the fertilizer phosphorus. The phosphorus data for tops at maturity plotted in Figure 3 were calculated from data in Table 4 by including grain and stray together. It may be observed in Figure 3 that the per cent of phosphorus of both tops and roots declined generally from the 4-week harvest to meturity. This indicates that the phosphorus content of plants, in addition to being a function of aveilable phosphorus in the soil, is a function of the stage of maturity of the plants.

For the selection of a soil to extractant ratio to be employed in this study, an investigation was made with the 3 extracting solutions: $0.1 \mathrm{~N} \mathrm{HCl}+0.03 \mathrm{~N} \mathrm{NH}_{4} \mathrm{~F}, 0.025 \mathrm{~N} \mathrm{HCl}+0.03 \mathrm{~N} \mathrm{NH}_{4} \mathrm{~F}$ and $0.1 \mathrm{~N} \mathrm{HCl}$. Results of this investigation appear in graphic form in Figure 5. A time of 1 minute was chosen as the shaking time. Bray and Kurtz (9), in using the above solutions containing $\mathrm{NH}_{4} \mathrm{~F}$, used a shaking time of 40 seconds and a soll to extractant ratio of 1:7. They considered that the $0.1 \mathrm{~N} \mathrm{HCI}+0.03 \mathrm{~N} \mathrm{NH}_{4} \mathrm{~F}$ solution removed acid-soluble and adsorbed phosphorus and that the $0.025 \mathrm{~N} \mathrm{HCI}+0.03 \mathrm{~N} \mathrm{NH} 4$ solution removed only adsorbed phosphorus. Figure 5 shows curves which were plotted from data collected in this study. A soil to extractant ratio of 1:40 was chosen for routine phosphorus extraction in the remainder 


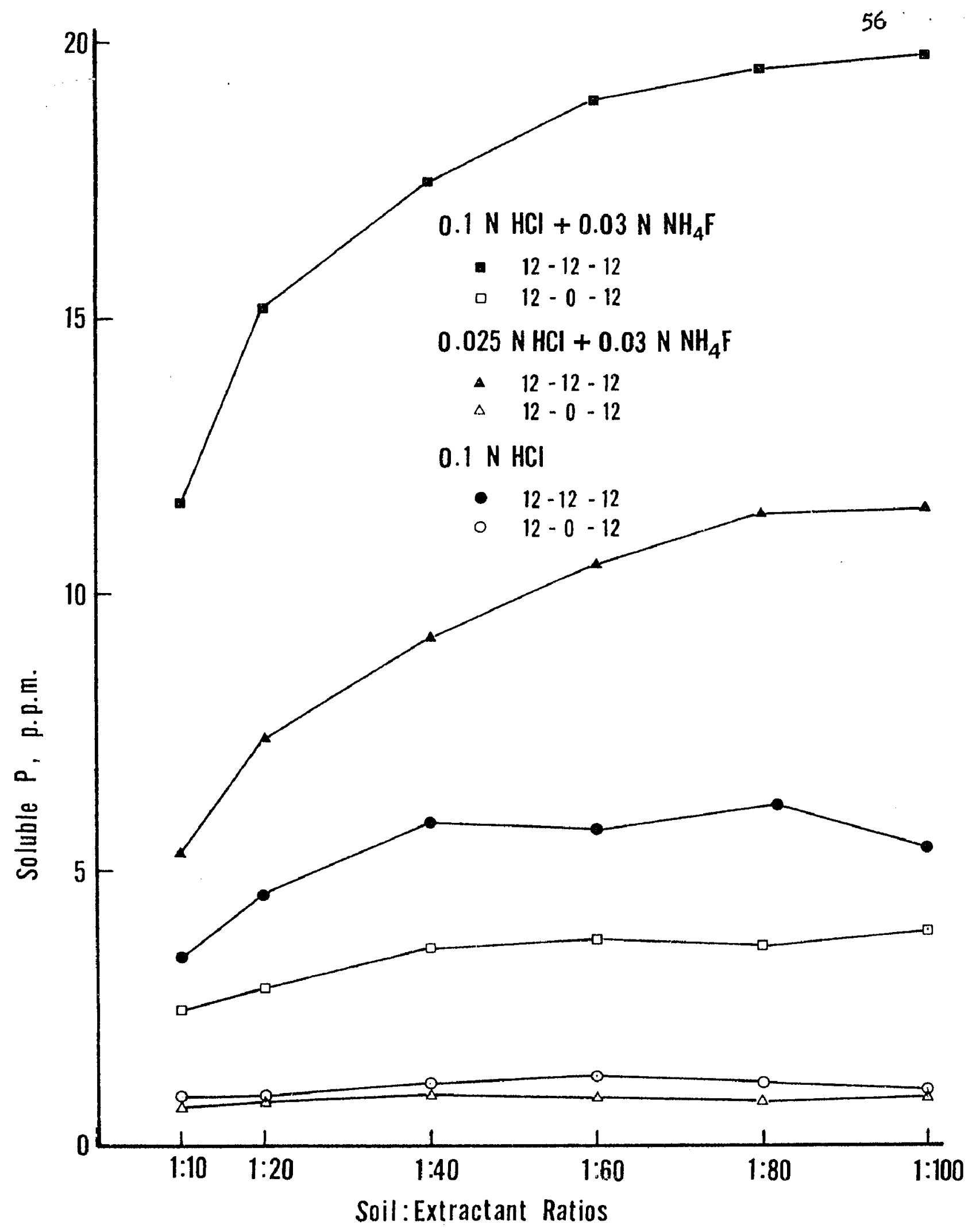

Figure 5.- Effects of extractants and soil to extractent ratios on tho phosphorus dissolved from Lake Charles clay in which 12-12-12 and 12-0-12 hed been mixed 4 weeks previously. 
of the study. Curves plotted in Figure 5 indicate that the Lake Charles clay contained both acid-soluble and adsorbed forms of phosphorus. It may be noted from the curves representing phosphorus extracted from soil treated with $22-0-12$ that with none of the soil to extractant ratios used does the summation of phosphorus extracted with the $0.1 \mathrm{~N}$ $\mathrm{HCl}$ solution and with the $0.025 \mathrm{~N} \mathrm{HCI}+0.03 \mathrm{~N} \mathrm{NH} / \mathrm{F}$ solution reach the value obtained rith the $0.1 \mathrm{~N} \mathrm{HCI}+0.03 \mathrm{~N} \mathrm{NH}{ }_{4} \mathrm{~F}$ solution. This indicates that the $0.1 \mathrm{~N} \mathrm{HCl}$ solution did not dissolve as much phosphorus as Bray's "acid soluble" phosphorus, which is the difference in values obtained with the $0.1 \mathrm{~N} \mathrm{HCI}+0.03 \mathrm{~N} \mathrm{NH}_{4} \mathrm{~F}$ and the $0.025 \mathrm{~N} \mathrm{HCI}+0.03 \mathrm{~N} \mathrm{NH}_{4} \mathrm{~F}$ solutions, that the $0.025 \mathrm{~N} \mathrm{HCI}+0.03 \mathrm{~N} \mathrm{NH}_{4} \mathrm{~F}$ solution did not obtain all of the "adsorbed" phosphorus, that re-fixation may have occurred or that the extra phosphorus obtained with the $0.1 \mathrm{~N} \mathrm{HCI}+0.03 \mathrm{~N} \mathrm{NH} 4^{\mathrm{F}}$ solution was due to the complementary action of the hydrogen and fluoride ions. Upchurch (100) found similar results in studies with olivier silt loam. From curves in Figure 5 representing phosphorus dissolved from soil treated with 12-12-12 it may be ascertained that Bray's "acidsoluble" phosphorus value was not equalled by the value obtained with the $0.1 \mathrm{~N} \mathrm{HCl}$ solution at soil to extractant ratios more narrow than 1:80. Byrnside and Sturgis (10) observed similar tendancies. By comparing the relative positions of all of the curves in Figure 5 it may be concluded that relatively more of the applied phosphorus occurred in fractions other than the acid-soluble.

Table 5 contains soil phosphorus values obtained with the 3 extractants at the 4 different harvest periods. The small differences 
Table 5.- Relationships of soil phosphorus, fertilizer phosphorus, plecement and period of growth of oats to the amounts of phosphorus extracted from Lake Charies clay at different sempling periods by three extractants.

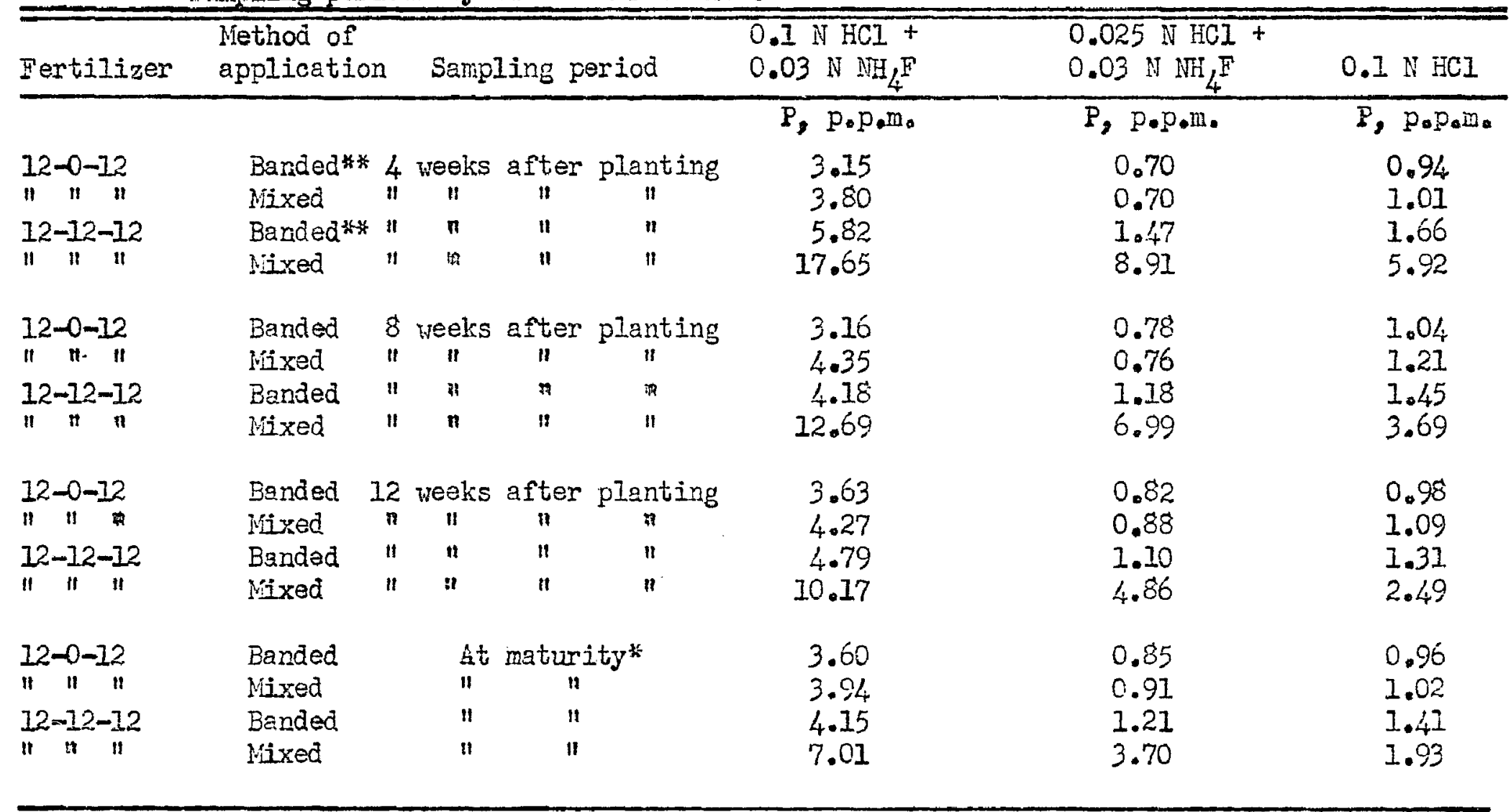

* The plants treated with 12-0-12 were harvested 26 weeks after date of planting. The plants treated with 12-12-12 were harvested 22 weeks after date of planting.

* Samples were taken an inch or more from the fertilizer band. 
between the values obtained for the $12-0-12-b a n d e d$ and the $12-12-12-$ banded treatments indicate very little phosphorus movement from the band. Data in Table 8 strongly support this view. The 0.1 N HCI + $0.03 \mathrm{~N} \mathrm{NH}_{4} \mathrm{~F}$ solution, used for the removal of adsorbed and acid-soluble phosphorus, more nearly characterized the available phosphorus in the soil than did either of the other extractants. Calculations, using values of phosphorus obtained with this extractant at the 4-week and at the 8-week harvests for the 12-12-12-mixed treatment, indicate that plant growth accounted for a reduction of 5.0 p.p.m. in the phosphorus value in the soil. Calculations from 4-week and 8-week harvest data in Tables 1 and 2 for the 12-12-12-mixed treatment, show an actual plant removal of 4.3 p.p.m. of phosphorus from the soil. Similar calculations, using 4-week and 12-week phosphorus date from Table 5, show that plants, during this 8 weeks of growth, accounted for a reduction in the phosphorus value in the soll of 7.5 p.p.m. Calculations using data in Tables 1 and 3 , reveal an actual removal of 8.1 p.p.m. of phosphorus from the soil during the same period of time. Calculations using data from 4-week and maturity periods in Table 5 show that plant growth accounted for a reduction in the phosphorus value in the soil of 10.6 p.p.m., whereas, date in Tables $I$ and 4 may be used in calculations to show that an actual removal of 18.8 p.p.m. of phosphorus from the soil occurred. Calculations using yield and phosphorus-content data in Table 4 show an actual removal of $21.1 \mathrm{p} . \mathrm{p} . \mathrm{m}$. of phosphorus from the soil by plants growing in the 12-12-12-mixed treatment during the period of growth from date of planting to maturity. Since the plants actually 
absorbed more phosphorus than the total amount extracted by the $0.1 \mathrm{~N}$ $\mathrm{HCl}+0.03 \mathrm{~N} \mathrm{NH}_{4} \mathrm{~F}$ solution, the extractant which extracted more than oither of the other extractants, need is indicated for work with this extractant at wider soll to extractant ratioa and at greater shaking times in order to remove the soil phosphorus in greater quantities. Further support is added to this view when it is observed in Table 6 that the quantity of phosphorus extracted from the 12-0-12 treatment of the uncropped soll was generally less than $4 \mathrm{p} \cdot \mathrm{p} . \mathrm{m}$. by use of the $0.1 \mathrm{~N} \mathrm{HCl}+0.03 \mathrm{~N} \mathrm{NH}_{4}$ 'solution and that the Fried and Dean A-values, Table 7, reached above the 5.p.p.m. level.

A good extractant is one which will remove from the soil an amount of the element proportional to that removed by plants. If the amount removed by the extractant were higher than the amount removed by plants, errors in determination and in calibration would have less effect on recommendations than when the amount removed by the extractant is lower than the amount romoved by plants.

Table 6 contains phosphorus data from soil which was uncropped. The information contained in this table indicates that there was very littlo change in the availability of soil and of fertillzer phosphorus during the 4 to 22-week period following mixing $12-0-12$ and $12-12-12$ with the soil. Since 32.5 p.p.m. of phosphorus were applied in the case of the 12-12-12 treatment, it is evident that a considerable portion of the applied phosphorus was fixed during the first 4-week period following mixing with the soil.

Table 7 shows a continuous increase with time in the Fried and 
Table 6.- Effects of fertilizers mixed well with Lake Charles clay on the amounts of phosphorus soluble in three extractants at difierent sampling periods after application of fertilizers to soil which remained uncropoed.

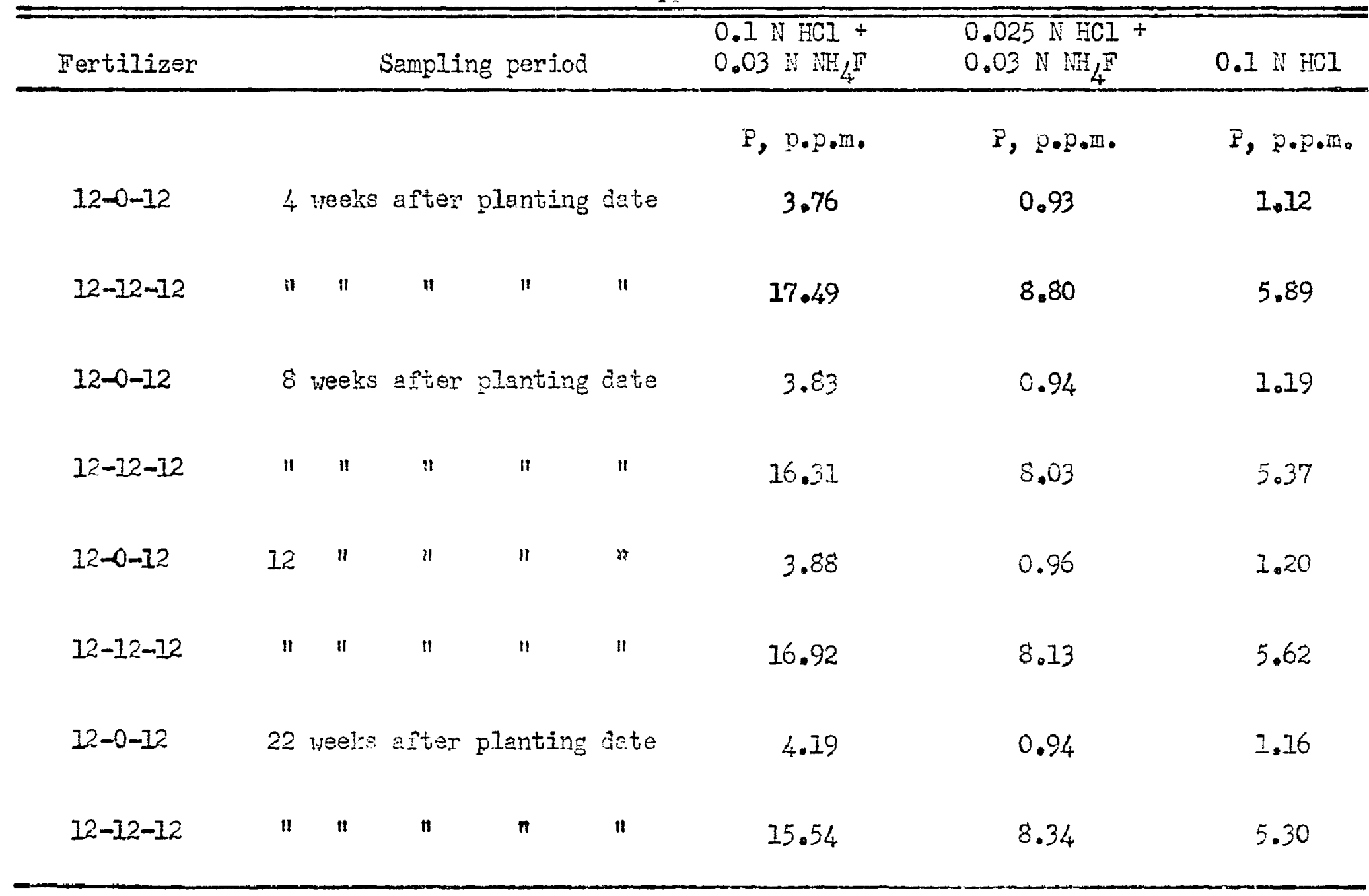


Table 7.- Fried and Dean A-values and soil phosphorus actually absorbed without phosphorus being added.

\begin{tabular}{|c|c|c|c|c|c|c|c|}
\hline Fertilizer & $\begin{array}{l}\text { Method } \\
\text { applicat }\end{array}$ & Ion & Samp & pling & period & $\begin{array}{l}\text { Soil P } \\
\text { in plants } \\
\text { as A-value }\end{array}$ & $\begin{array}{l}\text { Soil P } \\
\text { actually } \\
\text { absorbed }\end{array}$ \\
\hline & & & & & & $\mathrm{P} \cdot \mathrm{P} \cdot \mathrm{m}$. & $p \cdot p \cdot m_{0}$ \\
\hline $12-0-12$ & Banded & 4 & weeks & after & plenting & - & 0.24 \\
\hline 11111 & Mixød & $"$ & $"$ & $n$ & $1 "$ & - & 0.18 \\
\hline $12-12-12$ & Banded & 11 & $\sharp$ & $"$ & $"$ & 0.73 & - \\
\hline " $" 1$ & Mixed & $"$ & $"$ & $" 1$ & $"$ & 3.89 & - \\
\hline $12-0-12$ & Banded & 8 & weeks & after & planting & - & 0.47 \\
\hline 1111 & Mifred & 11 & 11 & 11 & 11 & - & 0.32 \\
\hline $12-12-12$ & Banded & $" 1$ & $"$ & $" 1$ & $"$ & 0.94 & - \\
\hline$" 11 "$ & Mixed & $"$ & $"$ & $"$ & $n$ & 4.22 & - \\
\hline $12-0-12$ & Banded & 12 & weoks & after & planting & - & 0.68 \\
\hline$\| n$ & Mixed & $"$ & $"$ & " & $"$ & - & 0.68 \\
\hline $12-12-12$ & Banded & 11 & 11 & " & " & 3.45 & - \\
\hline " $" ~ " ~$ & Mixed & $"$ & 11 & $"$ & " & 5.29 & - \\
\hline $12-0-12$ & Banded & & At & matur & ity & - & 1.10 \\
\hline 11 & Mixed & & " & $n$ & 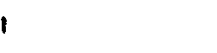 & - & 1.26 \\
\hline $12-12-12$ & Banded & & $"$ & $"$ & i & H出前 & - \\
\hline " & Mixed & & it & " & 1 & 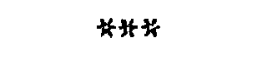 & - \\
\hline
\end{tabular}

Both tops and roots of plants used in calculations.

* The piants treated with 12-0-12 were harvested 26 weoks after date of planting. The plants treated with 12,-12-12 were harvested 22 weeks after date of planting.

* * A-values could not be determined due to the relatively short half-life of $\mathrm{p}^{32}$. 
Dean A-values for available soil phosphorus in the 12-12-12 treatments. The values representing the 12-12-12-banded treatment, however, did not closely approach the magnitude of the A-values obtained from the 12-12-12-mixed treatment until the 12-week harvest. The A-values from the 12-12-12-inixed treatment tend to be confirmed by data in Table 6 concerning the 12-0-12 treatment and the $0.1 \mathrm{~N} \mathrm{HCl}+0.03 \mathrm{~N} \mathrm{NH}_{4} \mathrm{~F}$ solution. If plants from the the 12-12-12 treatments had been analyzed for A-values at a later time, higher A-values would likely have been found. It is concluded that the A-values obtained from the 12-12-12mixed treatment throughout the period of observation were more highly associated with the "available" phosphorus values determined by other means than were the A-values obtained from the 12-12-12-banded treatment. In Table 7 are values of soil phosphorus actually absorbed by plants growing in the 12-0-12 treatments. Due to the extremely low amount of available soil phosphorus and a possible imbalance among fertilizer nutrients created by the application of a 12-0-12 fertilizer, the plants treated with 12-0-12 fertilizer were unable to absorb as much soil phosphorus as the Fried and Dean A-values and other "available" phosphorus values determined indicate as being available.

Radioactivity determinations of soil samples shown in Table 8 indicate that only a very small amount of the phosphorus placed in bands moved from the bands to a distance as great as 1 inch from the band. It appears that practically all of the phosphorus applied in bands remained in the approximate chemical forms as when it was applied or that it was fixed in the soil in a relatively small zone near the bands. The 
Table 8.- Movement of phosphorus from banded 12-12-12 fertilizer in Lake charles clay as indicated by radioactivity of soil samples.

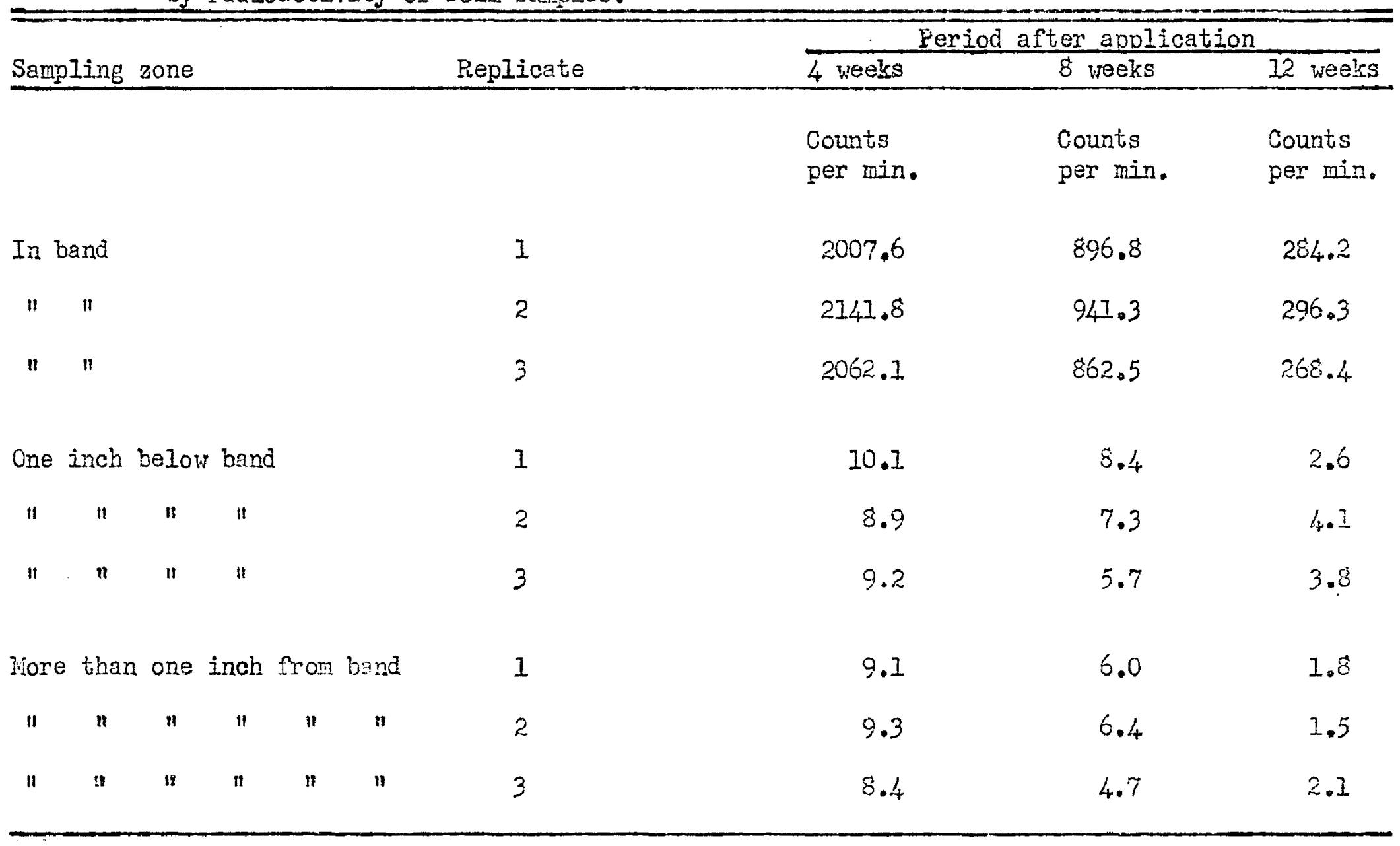


Wigh clay content of this soil and the low amount of phosphorus movement strongly indicate a high amount of phosphorus adsorption on the clay colloids or chemical precipitation at the colloidal surfaces. 
SUMMARY AND CONCLUSIONS

A study was made of the availability of native and fertilizer phosphorus in Lake Charles clay. Oats were used as the indicator crop.

The yield of oats as forage at different stages of growth and in grain at maturity was studied, and the total phosphorus content of the plants was determined at each of 4 harvests. The fertilizer phosphorus content of the plants was determined at the first 3 harvests by means of radioisotope techniques employing $\mathrm{p} 32$ in fertilizer.

Different solutions were used as extractents for the removal of phosphorus from the soil. Part of the phosphorus values were used to study relationships of phosphorus flxation and time. Other values were compared with actual amounts of phosphorus absorbed by the planis and with calculated Fried and Dean A-values.

A study was made of the approximate degree of phosphorus movement from the fextil.izer band by determination of radioactivity of soil samples.

Iields from the 12-12-12-banded and the 12-12-12-mixed treatments were signiflcantly greater than yields from the 12-0-12-banded and the 12-0-12-mixed treatments, respectively, at all harvosts. Forage yield from the 12-12-12-banded treatment, at each of the first 3 harvests, was significantly higher than forage yield from the 12-12-12-mixed treatment. There was no significant difference between grain yields from the 12-12-12-banded and the 12-12-12-mixed treatments. There was no significant difference between yields from the 12-0-12-banded and 
the 12-0-12-mixed treetments at either harvest period. It was concluded that phosphorus is needed in fertilizers for use on Lake Charles clay soil, that band placement of a balanced fertilizer will produce higher forage yields than mixing the fertilizer with the soil and that either mixing or banding fertilizer serves equally well for grain production.

The total phosphorus content of the plants which grew in soil receiving phosphorus treatment was higher throughout the experiment then that of plants which grew in soil receiving no phosphorus. The initial difference in phosphorus content between plants receiving the 12-12-12-banded and the 12-12-12-mixed treatments had disappeared by the 8-week harvast. Over the period studied, more fertilizer phosphorus was absorbed by plants receiving the 12-12-12-banded treatment than was absorbed by plants receiving the 12-12-12-mixed treatment but soil phosphorus was absorbed in larger quantities by plants receiving the 12-12-12-mixed treatment than was absorbed by plants receiving the 12-12-12-banded treatment. It is concluded that phosphorus fertilization on Lake Charles clay soil will cause phosphorus content of plants to be increased. Band placement, as compared with mixing of fertilizer containing phosphorus with the soil, will account for higher phosphorus content of plants for only a few weeks but will effect a yield advantage for a longer period.

Only a slight tendancy towards additional phosphorus fixation occurred after the 4-week period in soil which remained uncropped. Phosphorus extracted from the soil by use of the $0.1 \mathrm{~N} \mathrm{HCI}+0.03 \mathrm{~N}$ 
$\mathrm{NH}_{4} \mathrm{~F}$ solution more nearly characterized the phosphorus available to plants than did that from either of the other two extractants. Values obtained with this extractant compared ravorably with Fried and Dean A-values.

Phosphorus movement from the band during the 12-week period follow ing application was negligible. The high clay content of the soil and its high phosphorus-fixing capacity apparently accounted for the Iimitation on phosphorus movement.

This study indicates that the selection or development of a suitable extracting agent for phosphorus is of prime importance. It also further supports the fact that radiolsotopes are valuable tools for use in the scquisition of chemical and biological information not readily obtainable by other means. 
I. AIIen, Seward E., Speer, Robert J., and Maloney, Margaret. Fhosphate fertilizers for the Texas blacklands: II. Utilization of phosphate as influenced by plant species and by placement and time of application. Soil Sci. 77:65-73. 1954.

2. Ballard, Stanley S., and Dean, I. A. Soil studies with radioactive phosphorus: Significance of biological measurements of retention of applied phosphorus by soils. Soil Sci. 52:173-183. 1947 .

3. Baver, I. Do, and Brunner, F. H. Rapid soll tests for estimating the fortility needs of Missouri soils. Missouri Agr. Bxp. Sta. BuI. 404. 1939.

4. Bear, F. E., and Toth, So J. Phosphate fixation in soil and its practical control. Ind. Eng. Chem. Anal. Ed. 34:49. 1942.

5. Blume, James M. Radiation effects on plants grow in soil treated with fertilizer containing P32. Soil sei. 73:299-303. 1952.

6. Blume, James M., Hagen, C. E., and Mackie, Ruth 1. Radiation injury to plants grow in nutrient solutions containing P32. Soil Sc1. 70:415-426. 1950 .

7. Bouldin, D. R., and Black, C. A. Phosphorus diffusion in soils. So1l Sc1. Soc. Amer. Proc. 18:255-259. 1954.

8. Bray, R. H. A field test for available phosphorus in soils. IIJ. Agr. Bxp. Sta. BuI. 337. 1939.

9. Bray, Roger H., and Kurtz, E. T. Determination of total, organic, and available forms of phosphorus in soils. Soil Sci. 59: 39-45. 1945.

10. Byrnside, D. S., Jr., and sturgis, M. B. Soil phosphorus and its fractions as related to response of sugar cane to fertilizer phosphorus. La. Agr. Exp. Sta. Bul. 513. 1958.

11. Carter, W. T. The soils of Texas. Tex. Agr. Exp. Sta. Bul. 431. 2931.

12. Comar, C. I. Radiolsotopes in Biology and Agriculture. MaGrawHill Book Company, Inc., New York. 1955.

13. Radioisotopes in nutritional trace element studies. Nucleonics $3: 32-45$. 1948 . 
14. Cook, R. L. Divergent influence of degree of base saturation of soils on the availebility of native, soluble and rock phosphate. Jour. Amer. Soc. Agron. 27:297-311. 1935.

15. Cotton, Robert H. Determination of nitrogen, phosphorus and potassium in leaf tissue. Ind. Eng. Chem. Anal. Ed. 17:734-738。 1945.

16. Davis, FrankIin I. Retention of phosphates by solls: I. Effect of additions of iron and aluminum chloride upon the retention of phosphorus by virgin Hammond very fine sandy loam. Soll Sci. $56: 457-478$. 1943

17. Davis, L. E. Sorption of phosphates by non-calcareous Hawaiian soils. Soil Sei. 40:129-158. 1935.

18. Dean, I. A. An attempted fractionation of the soil phosphorus. Jour. Agr. Sc1. 28:234-244. 1938 .

19. Destribution of the forms of soil phosphorus. Soil Sci. Soc. Amer. Froc. 2:223-227. 1937.

20. - Tixation of soil phosphorus. Advences in Agron. I:39I411. 1949.

21. Dean, I. A., and GledhIII, V.H. Influence of soil moisture on phosphate adsorption as moasured by an axcised root technique. Soil Sci. 82:71-79. 1956.

22. Dean, L. A., Nelson, W. L., Mackenzie, A. J., Armiger, H. H., and Hill, W. I. Application of radioactive tracer technique to studies of phosphatic fertilizer utilization by crops: I. Greenhouse experiments. Soil Sci. Soc. Amer. Froc. 12:107112. 1947 .

23. Dean, L. A., and Rubins, E. J. Absorption by plants of phosphorus from a clay-water system: Methods and ensuing observations. Soil Sc1. 59:437-448. 1945 .

24. Delahay, Paul. Instrumental analysis. The Maclillan Company. New York. 1957.

25. Demolon, A., and Borbier, G. La concentration critique d'équilibre et I'appreciation du besoin des sols en acide phosphorique. Proc. Second Internatl. Cong. Soil Sci. Comm. IV:86-96. 1930.

26. Diclman, S. R., and Bray, R. H. Colorimetric method for the determination of phosphate. Ind. Eng. Chem. Anel. Ed. 12:665-668. 1940.

27. - Replacement of adsorbed phosphate from kaolinite by fluoride. Soil Sci. 52:263-273. 1941. 
28. Eid, M. T., Black, C. A., and Kempthorne, O. Importance of soll organic and fnorgenic phosphorus to plant growth at low and high soil temperatures. Soil Sci. 71:361-370. 1951.

29. Enlis, Roseoe, Jr., and Truog, Mhil. Phosphate fixation by montmorilfonite. Soil Sci. Soc. Amer. Proc. 19:451-454. 1955.

30. Fisher, R., and Thomas, R. P. The determination of the forms of inorganic phosphorus in soils. Jour. Amer. Soc. Agron. 27: 863-873. 1935.

31. Fiske, Cyrus H., and Subbarow, Yellapragada. The colorimetric determination of phosphorus. Jour. Biol. Chem. 66:375-400. 1925.

32. Ford, M. C. The nature of phosphate fixation in soils. Jour. Amer. Soc. Agron. 25:134-144. 1933.

33. Traps, G. S. Eiffect of additions on availability of soil phosphates Tex. Agr. Exp. Sta. Buz. 178. 1915.

34. Soils of Bell, Jefferson, Smith, Taylor and Webb Counties. Tex. Agr. Exp. Sta. BuI. 301. 1922.

35. The fixation of phosphoric acid by the soil. Tex. Agr. Exp. Sta. Bul. 304. 1922.

36. Fraps, G. S., and Fudge, J. F. Rapid chemical methods for the estimation of the capacity of the soil to supply phosphoric acid to plants. Jour. Amer. Soc. Agron. 25:217-230. 1933.

37. Fried, Maurice, and Dean, L. A. A concept concerning the measurement of available soil nutrients. Soil Sci. 73:263-271. 1952.

38. Fried, Maurice, Hagen, E. E., Stiz Del Rio, J. F., and Leggett, J. E. Kinetics of phosphate uptake in the soil-plant system. Soll Sci. 84:427-437. 1957 .

39. Ghani, $M .0$. , and Islam, A. Use of $8(\mathrm{OH})$ quinoline and selenious acid in determining available phosphorus. Soil Sci. 84:445451. 1957.

40. Golden, Laron E. Relationship of absorption of plant nutrients and fertilizer formulas in production of corn. Masters thesis. La. State Univ., Baton Rouge, La. 1951.

41. HaIl, N. S., and MacKenzie, A. J. Measurement of radioactive phosphorus. Soil Sci. Soc. Amer. Proc. 12:101-106. 1948. 
42. Harper, J. J. The easily soluble phosphorus content of soil as determined by electrolysis, extraction with dilute acid solution, and crop response to fertilization. Soil Sci. 35:1-16. 1933.

43. Hemwall, John B. The fixation of phosphorus by soils. Advances in Agron. IX:95-112. 1957.

44. The role of soil clay minerals in phosphorus fixation. Soil Se1. 83:101-108. 1957.

45. Hendricks, S. B., and Dean, L. A. Basic concepts of soil and fertilizer studies with radioactive phosphorus. Soil Sei. Soc. Amer. Proc. 12:98-100. 1947.

46. Hibbard, $\mathrm{Y}$. L. Factors influencing phosphate fixation in solls. Soil Sai. 39:337-358. 1935.

47. Howarth, Frank. Tissue suspensions for estimations of radioactivity. Nature 163:249. 1949.

48. Islam, M. A. Role of solid phase in phosphorus nutrition of plants as revealed by radioactive indicator. Soil sci. 81:439-442. 1956.

49. The role of solid phase in the phosphorus nutrition of plants. Soil Sci. 79:115-121. 1955.

50. Jackson, R. H. Organic phosphorus in New Zealand soils under pasture: I. Conversion of appl.ted phosphorus into organic forms. Soil Sci. 79:207-2I3. 1955.

51. Jordan, J., Sinkins, C., Corey, G., Knight, R., and Baker, G.0. Uptake and movement of fertilizer phosphorus. Soil Sci. 73= 305-313. 1952.

52. Kelley, Omer J., Hunter, Mlbert S., and Sterges, Athan J. Determination of nitrogen, phosphorus, potassium, celcium and magnesium in plant tissue. Ind. Fng. Chem. Anal. Ed. 18:319-322. 1945.

53. Kittrick, J. A., and Jackson, M. L. Common ion effect on phosphate solubility. Soil. Sci. 79:415-421. 1955.

54. Kurtz, Touby, DeTurk, Frnest E., and Bray, Roger H. Phosphete adsorption by Illinois soils. Soil Sci. 61:111-124. 1946.

55. Lewis, G. G., Jordan, J. V., and Juve, R. L. Effect of certain cations and anions on phosphorus availability. Soil Sci. 74: 227-232. 1952.

56. Mackenzio, A. J., and Dean, L. A. Procedure for measurement of $\mathrm{p} 31$ and $\mathrm{F} 32$ in plant material. Anal. Chem. 30:559-560. 1948. 
57. MacKenzie, A. J., and Dean, I. A. Measurement of F32 in plant material by the use of briquets. AnaI. Chem. 22:489-490. 1950.

58. Mackie, Ruth H., Blume, James M., and Hagen, C. T. Histologiogl changes induced in barley plants by radiation from $\mathrm{P}^{32}$. Amer. Jour. Bot. 39:229-237. 1952.

59. Matuliffe, Clayton. Determination of radiophosphorus in plant materièl by solution counting. Anal. Chem. 21:1059-106I. 1949.

60. MaAuliffe, Clayton, and Bradfield, Richard. Utilization by plants of phosphorus in farm manure: III. Uptake of phosphorus by Sudan grass from manure and superphosphate incorporated into soil at different depths. Soil Sci. 79:475-486. 1955.

6I. Mckuliffe, C. D., Hall, M. S., Dean, L. A., and Hendricks, S. B. Exchange reactions between phosphates and soils: Hydroxylic surfaces of soil minerals. Soil Sci. Soc. Amer. Proc. 12: 119-123. 1947 .

62. McLean, E. O. Factors affecting yields and uptake of phosphorus by different crops: II. Rock phosphate and superphosphate, separate and in combination, under extiended cropping. Soil Sci. 82:181-192. 1956 .

63. MeLean, E. O. and Hoelscher, J. I. Pactors affecting yields and uptake of phosphorus by different crops: I. Previous applications to the soil of rock phosphate and superphosphate. Soil Sci. 78:453.462. 195/.

64. Milier, J.R., and Axley, J.H. Correlation of chemical soil tests for available phosphorus with crop response, including a proposed method. Soil Sci. 82:117-127. 1956.

65. Horgan, M. F. The universal soil testing system. Conn. Agr. Exp. Sta. Bul. 392. 1937.

66. Morrison, Frank B. Feeds and Feeding. The Morrison Publishing Company. Ithaca, New York. 1956.

67. Nelson, W. I., Krantz, B. A., Colwell, T. E., Woltz, W. G., Hawkins, Arthur, Dean, I. A., MacKenzie, A. J., and Rubins, E. J. Application of tracer technique to studies of phosphatic fertilization utilization by crops: II. Field experiments. Soil Sci. Soc. Amer. Proc. 12:113-118. 1947.

68. Olsen, Sterline R., and Gardner, Robert. Utilization of phosphorus from various fertilizer materials: IV. Sugar beets, wheat, and barjey in Colorado. Soil Sc1. 68:163-169. 1949. 
69. Parker, F. I. Recent studies on the phosphate content of the soil solution and its relation to the phosphorus nutrition of the plant. Proc. 1st Internat1. Cong. Soil. Sci. 2:384-395. 1927.

70. Fhosphorus in soils and fertilizers. Sci. 3:215-220.

77. Farks, R. Q., Hood, S. Lo, Hurwitz, Charles, and Ellis, G. H. Quantitetive chemical microdetermination of twelve elements in plant tissue. Ind. Zng. Chem. Angl. Ed. 15:527-533. 1943.

72. Perkins, Alfred T., Dragsdorf, R. Dean, Lippincott, E. R., Selby, Jack, and Fateley, W. G. Froducts of clay mineral decomposition as related to phosphate fixation. Soil Sci. 80:109-120. 1955.

73. Pesek, John. The absorption of phosphorus from phosphate fertilizers applied to established meadows: III. Effect of phosphorus source and placement and of meadow composition. Soll Sci. Soc. Aner. Froc. 19:63-66. 1955.

74. Pierre, W. H., and Norman, A. G. Soil and fertilizer phosphorus. Academic Press, Ino. New York. 1953.

75. Prince, Allan B. Residual effects of superphosphate application on soll. phosphorus level and growth of crimson clover as measured by yield and phosphorus uptake. Soil Sci. 75:51-57. 1953.

76. Pugh, A. J. Lams of soil colloidal behavior. III. Colloidal phosphates. Soil Sci. 38:315-334. 1934.

77. Rabideau, Glenn S., Whaley, W. Gordon, and Heimsch, Charles. The absorption and distribution of radioactive phosphorus in two maize inbreds and their hybrid. Amer. Jour. Bot. 37:93-99.1950.

78. Ravikovitch, S. Anion exchange: I. Adsorption of the phosphoric acid ions by soils. Soll. Sci. 38:219-239. 1934。

79. Anion exchange: II. Liberation of the phosphoric acid lons adsorbed by soils. Soil Sci. 38:279-290. 1934.

80. Influence of exchangeable cations on availability of phosphate in soils. Soil sci. 47:357-366. 1938.

81. Reed, J. Fielding, and Sturgis, M. B. Chemical characteristics of the soils of the rice area of Louisiana. La. Agr. Exp. Sta. Bul. 307. 1939.

82. The use of chemical methods for the determination of availabie nutrients in Louisiana soils. La. Agr. Dxp. Sta. BuI. 313. 1939. 
83. Rjewe, Marvin I., and Smith, J. C. Effect of fertilizer placement on perennial pastures. Tex. Agr. Exp. Sta. Bul. 805. 1955.

84. Rost, C. O., and Pinclney, R. H. Colorimetric methods for the determination of readily available phosphorus in soils. Jour. Amer. Soc. Agron. 24:377-395. 1932.

85. Russell, GIenn C., and Low, Fhilip F. Reaction of phosphate with kaolinite in dilute solution. Soil Sci. Soc. Amer. Fro. 18: 22-25. 1954.

86. Russell, R. Scott, and Mertin, R. F. Use of radioactive phosphorus in plant nutritional studies. Nature 163:71-72. 1949.

87. Scarseth, G. D. The mechanism of phosphate retiention by natural alumino-silicate colloids. Jour. Amer. Soc. Agron. 27:596616. 1935.

88. Scarseth, G. D., and Tidmore, J.W. Fixation of phosphate by soil colloids. Jour. Anner. Woc. Agron. 26:138-151. 1934.

89. Seatz, Iloyd F. Phosphate activity measurements in soils. Soil Sci. 77:43-51. 1954.

90. Sherman, Kildred 5 . Colorimetric determination of phosphorus in soils. Ind. Eng. Chem. Anal. ed. 14:182-185. 1942.

91. Snedecor, G. W. Statistical methods. Towa State Press. Ames, Iova. 1946.

92. Spinis, J. J. T., and Barber, S. A. Study of fertilizer uptake using radioactive phosphorus. Sci. Agr. 27:145-156. 1947.

93. Stout, P.R. Alterations in the crystal structure of clay minerals as a result of phosphate fixation. Soil Sci. Soc. Amer. Proc. 4:177-182. 1939.

94. Stout, P. R., Overstreet, Roy, Jacobson, Louis, and Ulrick, Albert. The use of radioactive tracers in plant nutrition studies. Soil Sci. Soc. Amer. Proc. 12:91-97. 1947.

95. Teakle, I. J. H. Phosphate in the soil solution as affected by reaction and cation concentrations. Soil Sci. 25:143-162. 1928.

96. Thornton, S. F. The available phosphorus and potassium contents of surface soils and subsoils as show by Newbauer method and by chenical tests. Jour. Amer. Soc. Agron. 27:4,6-51. 1935.

97. Thorntion, S. F., Conner, S. D., and Fraser, R. R. The use of rapid chemical tests on soils and plants as aids in determining fertilizer needs. Ind. Agr. Exp. Sta. Cir. 204. 1934. 
98. Tolbert, N. Edward, and Pearson, Paul B. Atomic energy and the plant sciences. Advances in Agron. IV:279-303. 1952.

99. Truog, B. The determination of readily available phosphorus of soils. Jour. Amer. Soc. Agron. 22:874-882. 1930.

100. Upchurch, William J. Crops and Soils Departmental Annual Report for 1955. Louisiana State University Agricultural axperiment Station. Baton Rouge, Louisiana. 1955.

101. Weoks, M. $\mathbf{E}_{0}$, and Karraker, F. E. A comparison of various extracting solutions for measuring the availability of phosphorus in soils of known fertilizer treatment and crop performance. Soil Sci. 51:41-54. 194I.

102. Weiser, V. L. Fixation and penetration of phosphate in Vermont soils. Vt. Agr. Exp. Sta. BuI. 256. 1933.

103. Wiebe, Herman H., and Kramer, Paul J. Translocation of radioactive isotopes from various regions of roots of barley seedlings. Flant physiology 29:342-348. 1954.

104. Wiley, R. C., and Gordon, N. C. Availability of adsorbed phosphorus. Soil Sci. 15:371-372. 1923。

105. Wolf, Benjamin. Rapid photometric determination of total nitrogen, phosphorus and potassium in plant material. Ind. Ang. Chem. Lna1. 16. 16:121-123. 1944. 


\section{AUTOBIOGRAPHY}

\section{Laron Is, Golden was born in Clark County, Arkansas, on April 20,}

1920. His elementary education was received at a rural school near Arkadelphia, Arkansas, and his high school work was done at lurkadelphia, High School, Arkadelphia, Arkansas.

He served in the Aymy of the United States from December 1, 194I, to August 25,1945 , when he was released with the rank of second lieutenant after having served both in the armored force and in the infantry. He has served in the Army Wational Guard of the United States from 1946 to date as an engineer platoon leader, an engineer company commander and as an artillery operations officer with the ranks of first lieutentant, captain and mejor, respectively.

In september, 1945, he enrolled at Southern state College, Magnolia, Arkansas, and efter two years of school work there, transferred to the University of Arkensas, Payetteville, Arkansas. He graduated from the University of Arkansas with the degree of Bachelor of Science in general agriculture in January, 1949.

From January, 1949, to August, 1953, he was employed as instructor and as assistant professor of agronomy and horticulture at Southern State College, Magnolia, Arlansas. During this period, he was enrolled at Louisiana State University during the summer of 1949, the spring semester of 1950 and the summers of 1950 and 1951, obtaining the degree of Master of Science in agronomy in August, 195. . 
Since September, 1953, excepting a leave-of-absence period June, 1957, to August, 1958, he has been employed as assistant professor of agronomy at the University of Houston, and as manager of the University of Houston Demonstration Farm, Houston, Texas. During this period, he took science courses at the University of Houston and did most of the research work required for the $\mathrm{Ph}$. D. thesis. This course work and the research were done as a result of solicited suggestions and guidance from Dr. \%. B. Sturgis, Head, Department of Agronomy, Louisiana State University. liajoring in agronomy, he enrolled again in the Graduate School, Louisiana State University in the fall. semester of 1957 . He is now a candidate for the degree of Doctor of Philosophy in the Department of Agronomy, Louisiana State University. 
EXAMINATION AND THESIS REPORT

Candidate: Iron E. Golden

Major Field: Agronomy

Title of Thesis: The Availability of Native and Radioactive Fertilizer Phosphorus to Oats on Lake Charles Clay

Approved:
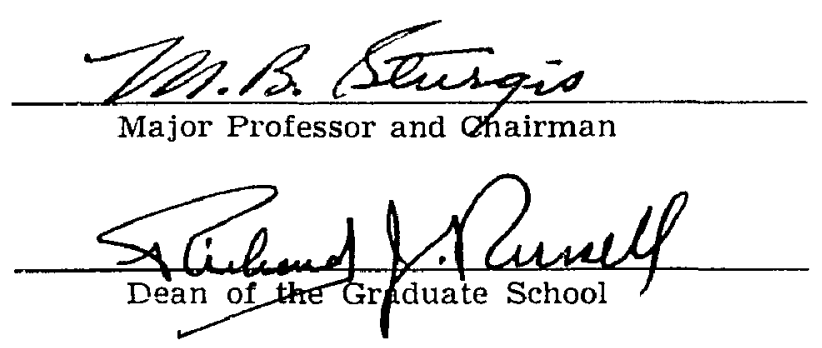

EXAMINING COMMITTEE:
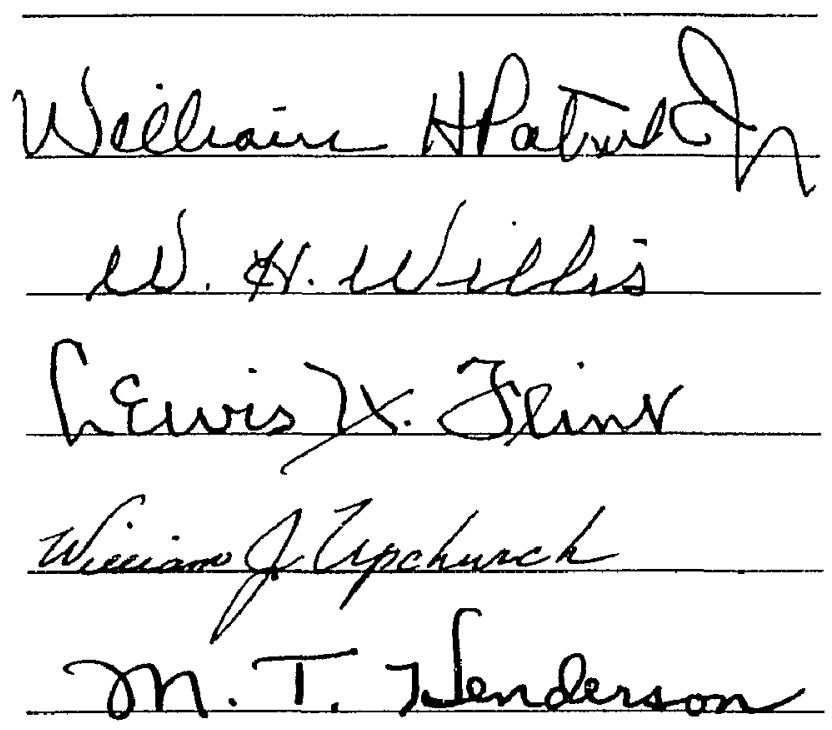

Date of Examination:

October 18,1958 